\title{
Habitat heterogeneity influences cold-seep macrofaunal communities within and among seeps along the Norwegian margin. Part 1: macrofaunal community structure
}

\author{
Carole Decker ${ }^{1,{ }^{*}}$, Marie Morineaux ${ }^{1}$, Saskia Van Gaever ${ }^{2}$, Jean-Claude Caprais ${ }^{1}$, Anna Lichtschlag $^{3}$, \\ Olivier Gauthier ${ }^{4}$, Ann C. Andersen ${ }^{5}$, Karine Olu ${ }^{1}$
}

\author{
${ }^{1}$ IFREMER Département Etude des Ecosystèmes Profonds, Plouzané, France \\ 2 Marine Biology Section, Department of Biology, Ghent University, Ghent, Belgium \\ ${ }^{3}$ Max-Planck-Institute for Marine Microbiology, Bremen, Germany \\ 4 Institut Universitaire Européen de la Mer, CNRS UBO IRD UMR 6539, Laboratoire des Sciences de \\ l'Environnement Marin, Plouzané, France \\ ${ }_{5}$ UPMC Université Paris VI, CNRS, UMR 7144, Station Biologique de Roscoff, Equipe Ecophysiologie des \\ Invertébrés Marins des Milieux Extrêmes, Roscoff, France
}

*: Corresponding author : Carole Decker, email address : carole.decker@ifremer.fr

\begin{abstract}
:
Håkon Mosby mud volcano (HMMV) is one of the most active and most studied seep sites in European waters. Many authors have described its thermal activity, dynamic of mud flows, and geochemical and microbial processes. It is characterised by a concentric zonation of successive biogenic habitats related to an activity and geochemical gradient from its centre to its periphery. Around the central area covered by mud flows, white and grey microbial mats occur among areas of bare sediment, whereas siboglinid tubeworm fields of Sclerolinum contortum and/or Oligobrachia haakonmosbiensis colonise the peripheral areas. The meiofaunal community is known to be structured among habitats, but the macrofauna has rarely been investigated and has never been sampled in situ. As part of the European project HERMES, using the ROVs Victor 6000 and Quest 4000, we sampled quantitatively the different habitats of the volcano for macrofauna sensus lato, retained on a 250- or 500$\mu \mathrm{m}$ sieve. We also sampled a newly discovered pockmark on Storegga slide (cne 5.6) and two pockmarks (G11, G12) in the Nyegga area. Macrofauna was identified and counted from phylum to family level. Our results on HMMV showed a gradient of increasing density and diversity from the volcano centre (1-3 taxa; $\left.260 \mathrm{ind} \cdot \mathrm{m}^{-2}\right)$ to the peripheral siboglinid fields (8-14 taxa, 93,000 ind $\cdot \mathrm{m}^{-2}$ ), with an intermediate situation for microbial mats. For macrofauna $\geq 500 \mu \mathrm{m}$, non-siboglinid polychaetes dominated the communities of the central mud volcano area, white mats and S. contortum fields (83, 89 and $37 \%$ of the total, respectively), whereas gastropods dominated grey mats and 0 . haakonmosbiensis fields ( 89 and $44 \%$ of the total, respectively). Polychaete families followed the same pattern of diversity according to habitats within HMMV. Of 23 polychaete families identified, only one occurred in the centre, and three in the microbial mats. Capitellidae and Dorvilleidae (typical of organically and sulphide-enriched areas) occurred at remarkably high densities in white microbial mats and in O. haakonmosbiensis fields. The S. contortum fields were the most diverse habitat with 12 polychaete families. The 250- $\mu \mathrm{m}$ fraction showed similar taxa dominating the habitats, but taking meiofauna into account, nematodes became the major taxon in white mats and in S. contortum fields, where they were particularly large in size, whereas copepods dominated in other habitats. Meiofauna and macrofauna did not show the same patterns of density according to habitats. Using principal components analysis the habitats at HMMV were clearly distinct, and clustered according to dominant species of siboglinids and type of microbial mats. Pockmarks at Nyegga showed a similar concentric pattern of habitats around fluid sources as on the volcano, which seemed similarly to influence macrofauna composition, but at a much smaller scale. Total taxa and polychaete diversity are high in the S. contortum fields in these pockmarks as well. Regional-scale comparisons including HMMV and Storegga suggested a higher influence of habitat-type than seep-site on the community structure.
\end{abstract}

Keywords : Cold-seep ; community structure ; macrofauna ; Norwegian margin ; Polychaeta 


\section{Introduction}

Cold-seep areas have been known for thirty years (Paull et al. 1984; Suess et al. 1985) on both active and passive continental margins, in the Pacific, Atlantic and Indian Oceans and Mediterranean Sea (Sibuet et al. 1998; Levin 2005). These environments are generally characterised by a very great biomass dominated by large symbiont-bearing invertebrates. The latter are considered ecosystem engineers which, together with microbial mats, generate very diverse habitats (Sibuet et al. 2002; Levin 2005). In the Gulf of Mexico and the Gulf of Guinea, habitat heterogeneity is created by dense bushes of siboglinid polychaetes (oincluding vestimentiferan tubeworms) and mytilid and vesicomyid bivalve beds (Bergquist et al. 2003a; Bergquist et al. 2005; Olu-Le Roy et al. 2007), whereas vesicomyids and microbial mats dominate the soft sediment seep areas along the Californian and Oregon margins (Sahling et al. 2002; Levin et al. 2003). Within the sediment and on carbonate crusts, the tubes and shells of these invertebrates support macro- and meiofaunal taxa at different densities and diversities.

Habitat geochemistry has been suggested to be the key to the foundation of the various habitats: methane and oxygen concentrations in water have been identified as factors explaining the distribution of the different symbiont-bearing taxa (Olu-Le Roy et al. 2007), and also as driving mussel-bed community structure (Bergquist et al. 2005). However, in soft deep-sea sediment containing methane fluid or gas hydrates, sulfide concentrations influence the fine-scale distribution of macrofaunal assemblages, symbiont-bearing taxa and their associated species (Sahling et al. 2002; Levin et al. 2003). Community succession has also been attributed to epibenthic sulphide concentrations in vestimentiferan aggregations (Cordes et al. 2005). Moreover, the physical structure created by the foundation species can also affect the community structure as demonstrated in tubeworm fields of the Gulf of Mexico (Cordes et al. 2005) or in shallow-water habitats (e.g. Zhulke, 1998). The biogenic habitats at seeps differ in their 3-dimensional structural diversity, nutrient sources and inter-specific interactions, adding levels of complexity besides geochemical gradients (Cordes et al. 2010).

Mud volcanoes are typically kilometre-scale structures formed by the expulsion of methanerich fluidized mud expelled through a central conduit (Brown et al. 1988; Le Pichon et al. 1990; Vogt et al. 1997). The thermal and geochemical gradients from the centre to the periphery of mud volcanoes result in a zonation of habitats, which were described by video surveys for several mud volcanoes (Olu et al. 1997; Olu-Le Roy et al. 2004; Jerosch et al. 2007a; Jerosch et al. 2007b). Nevertheless, the macrofaunal community structure and the habitat heterogeneity at the scale of a typical cold-seep geological structure, such as a mud volcano, have not been studied.

In this study we characterised the benthic macrofauna living in two cold-seep areas along the Norwegian margin: the Håkon Mosby mud volcano (HMMV) and pockmarks of the Storegga slide. The following questions were addressed:

(1) How are the macrofaunal communities living on HMMV and along the Storegga slide structured among habitats within a seep site?

(2) Does large sized meiofauna show similar patterns of variability among these habitats?

(3) How does macrofauna community structure vary among seeps at a regional scale?

(4) Does habitat biogeochemistry influence community structure? 


\section{Study area}

Seep communities were found at $1250 \mathrm{~m}$ water depth along the Norwegian margin at the time of the Håkon Mosby mud volcano discovery $\left(72^{\circ} \mathrm{N}, 1^{\circ} 44^{\prime} \mathrm{E}\right)$ (Vogt et al. 1997) (Fig. 1). As one of the most active mud volcanoes described thus far and probably the most studied, HMMV is caracterised by high rates of mud, fluid and gas ejections through the surface of the volcano (Sauter et al. 2006). Geothermal modelling indicates aqueous flow rates of up to 4-10 m yr $r^{-1}$ at the centre of the volcano rapidly decreasing to less than $1 \mathrm{~m} \mathrm{yr}^{-1}$ at its periphery (Kaul et al. 2006; Feseker et al. 2008). Related to this gradient of activity, concentric zones of seafloor morphology, litho-types, and geochemical and biological processes have been identified during successive surveys (Gebruk et al. 2003; Milkov et al. 2004; De Beer et al. 2006; Niemann et al. 2006b; Jerosch et al. 2007a; Felden et al. 2010; Lichtschlag et al. 2010). This circular (1 to $1.5 \mathrm{~km}$ diameter) structure is characterised by (1) a central zone apparently devoid of megafauna with mud and gas eruptions, (2) an intermediate zone covered by microbial mats ("white mats") dominated by Beggiatoa sp. (Niemann et al. 2006b) and highly diverse "grey mats" with a large number of filamentous bacteria (De Beer et al. 2006) and (3) a peripheral zone colonised by symbiont-bearing siboglinid polychaetes (Gebruk et al. 2003; Niemann et al. 2006b; Jerosch et al. 2007b; Lösekann et al. 2008). Two species of siboglinid tubeworms form these large fields: Sclerolinum contortum Smirnov, 2000 (Monilifera), which appears to be the dominant species according to the first video surveys, and Oligobrachia haakonmosbiensis Smirnov, 2000 (Frenulata) (Gebruk et al. 2003; Van Gaever et al. 2006; Jerosch et al. 2007b). Studies on faunal communities have characterised meiofauna $(32-500 \mu \mathrm{m})$ in the main habitats (centre of the volcano, microbial mats and siboglinid fields) (Soltwedel et al. 2005; Van Gaever et al. 2006; Van Gaever et al. 2009b) and macro- and megafauna in Siboglinidae fields (Gebruk et al. 2003), but quantitative data from ROV sampling were only obtained for meiofauna. These studies provided the first clues concerning the relationship between the structure of benthic communities and their habitats, with a decrease in diversity from the centre to the periphery that seems to be driven by a fluid-flow gradient. In the intermediate zone, covered by microbial mats, lower meiofaunal diversity than in siboglinid fields was detected, with only one genus of nematode (related to Geomonhystera disjuncta) that shows adaptations to low oxygen and high sulphide levels (Van Gaever et al. 2006).

In the southern part of the Norwegian margin, the Storegga area is a giant slide produced by a series of Holocene slope failures (Paull et al. 2008) with some pockmarks related to underlying gas chimneys, as revealed by seismic investigations (Hustoft et al. 2007; Paull et al. 2008; Foucher et al. 2009). Located between 600 and $900 \mathrm{~m}$ water depth $\left(64^{\circ} 40^{\prime 2} 2^{\prime \prime} \mathrm{N}\right.$, $\left.05^{\circ} 17^{\prime} 32^{\prime \prime} \mathrm{E}\right)$ (Fig. 1), these pockmarks were formed by fluids and gases seeping through the seabed, but their formation has not been accurately dated (Hustoft et al. 2007). Details on the rates of fluid flow and related biological processes within and adjacent to them are still not well understood (Hustoft et al. 2007). Detailed ROV surveys of individual pockmarks provided geochemical and biological proof of present or past seeps and chemosynthetic activity (Bayon et al. 2009; Foucher et al. subm). On the northeastern flank of this slide, called the Nyegga area, two pockmarks named G11 and G12 (about 300 m diameter) at 750 $\mathrm{m}$ depth have already been surveyed by the ROV (Hovland et al. 2006) but only G11 has been properly described in detail (Fig. 2). It is assumed that the Nyegga pockmarks were formed by a sudden (i.e. "catastrophic") fluid flow and that there is still some micro-seepage (diffusive methane flow) activity (Hovland et al. 2005). The first ROV dives revealed small living tubeworms covering pockmark G11. Inside this pockmark, small mounds have been described as "ice pingoes" and are assumed to be gas hydrate mounds (Hovland et al. 2006). During the VICKING cruise in 2006 observations and sampling by ROV Victor showed pingoes of Nyegga to be composed of mud accumulations with entangled Sclerolinum, soft enough to be sampled by a blade core (Vanreusel et al. 2009). 


\section{Materials and methods}

\subsection{Sampling strategy}

Three seep areas (Fig. 1) were studied: the Håkon Mosby Mud volcano, the Storegga slide and the Nyegga area about $14.4 \mathrm{~km}$ Northeast of the Storegga study site. A newly discovered pockmark (Cne 5.6) has been sampled on the Storegga slide and two at Nyegga (G11-G12). Although of different sizes, each of these sites is an individual geological structure related to deep sources by an individual chimney or conduit. Fluid or gas-rich mud escapes through a main central conduit (HMMV) or several scattered fluid seepages at Storegga and Nyegga pockmarks. In both cases, chemosynthesis-based communities are found around the seepage sources.

Macrofauna was sampled at the HMMV during the VICKING cruise (May-June 2006) aboard the RV Pourquoi pas? with the ROV Victor 6000 (chief scientist, H. Nouzé). During the ARKXXII/1b cruise (June-July 2007) aboard the RV Polarstern (chief scientist, M. Klages), additional samples were collected on the HMMV with the ROV Quest 4000.

According to visible zonation, six different biogenic habitats were sampled on the HMMV (Fig. 3): (1) centre of the volcano, devoid of megafauna and of any visible life at the sediment surface, (2) grey microbial mats, consisting of highly diverse filamentous bacteria, (3) white microbial mats dominated by Beggiatoa sp., (4) bare sediment adjacent to the white microbial mats, and tubeworm fields of tiny siboglinid polychaetes (previously called "pogonophoran") either dominated by (5) the frenulate Oligobrachia haakonmosbiensis or, (6) by the monolifera Sclerolinum contortum.

On Storegga slide, a pockmark called cne 5.6 was explored in detail and sampled. On the Northeastern part of the Storegga slide, in the Nyegga area, two other large pockmarks (about 300 m diameter), called G11 and G12, were also explored (Fig. 2). Seep sources were much smaller on these pockmarks than on HMMV, generally less than 1 meter in diameter, but also showed concentric zonation with reduced sediment in the centre surrounded by microbial filaments, gastropods and finally siboglinid fields of the two species Oligobrachia cf. haakonmosbiensis and Sclerolinum cf. contortum (Fig. 4). All these habitats (except the $O$. cf. haakonmosbiensis field) were sampled during the VICKING cruise at both the Storrega cne 5.6 site and at the Nyegga G11 and G12 pockmarks. Additionally one pingo colonised by siboglinid polychaetes was also sampled in the Nyegga area.

Macrofauna was sampled in duplicate or triplicate using small $\left(0.018 \mathrm{~m}^{2}\right)$ or large $\left(0.036 \mathrm{~m}^{2}\right)$ blade cores and a suction sampler, manipulated by the ROV (Table 1). On board the RV Polarstern, large blade core samples were divided in half, with each half having the same surface as small blade core samples. At HMMV, suction samples were taken over a surface of $0.04 \mathrm{~m}^{2}$ delimited by four laser points while the ROV was resting on the sediment. Suction samples consisted of - approximately - the first $5 \mathrm{~cm}$ of sediment. This is where most of the macrofauna is usually found in deep-sea sediments (e.g. Galeron et al. 2009) and in seep habitats, except in some large bivalve aggregations like vesicomyids (Menot et al. 2010). At HMMV, $80 \%$ of the nematodes have been found in the first $2 \mathrm{~cm}$ of sediment in both siboglinid fields and in microbial mats (Van Gaever et al. 2006). Suction samples and bladecores samples of the same habitats were taken less than $1 \mathrm{~m}$ away from each other. On the Storegga slide pockmarks, quantitative sampling could only be achieved in siboglinid fields, because the other habitats were fragmented and individual patches were too small. Some samples were thus considered to be non-quantitative samples and were not included in the statistical analyses (Table 1). 
Additionally, tube-core samples $(6 \mathrm{~cm}$ diameter, $30 \mathrm{~cm}$ length) were taken in the different habitats at HMMV and at the Nyegga pockmarks during the VICKING cruise (Table 2), to characterise the geochemistry (oxygen, sulphate and sulphide profiles) of the different habitats. A water multi-sampler (PEP), was used to collect water samples above each type of habitat (at 1 to $10 \mathrm{~cm}$ above the seafloor surface), to measure methane concentrations (Table 2).

\subsection{Sampling processing}

Blade-core sediment samples collected during the VICKING cruise were washed with filtered seawater and sieved on $1 \mathrm{~mm}$ and $500 \mu \mathrm{m}$ (square) mesh sizes, whereas suction water samples were sieved on $250 \mu \mathrm{m}$. In addition to studying macrofauna, the aim was also to complete the meiofaunal inventory $(32-500 \mu \mathrm{m})$ started by Van Gaever et al. (2006). The blade-core samples collected during the ARK-XXII cruise were successively sieved on $1 \mathrm{~mm}$, $500 \mu \mathrm{m}, 300 \mu \mathrm{m}$, and $250 \mu \mathrm{m}$. Whereas coastal macrofauna is commonly collected on a $1 \mathrm{~mm}$-sieve, deep-sea macrofauna is generally sieved on a mesh size smaller than $1 \mathrm{~mm}$, because only a very few species exceed $1 \mathrm{~mm}$. However, the lower size limit used for macrofauna has varied among previous studies done at seeps: sizes used have included $250 \mu \mathrm{m}, 300 \mu \mathrm{m}$ and $500 \mu \mathrm{m}$ or greater (Bergquist et al. 2003b; Levin et al. 2003; Cordes et al. 2005; Galéron et al. 2009; Menot et al. 2010). Our first comparaison of macrofauna

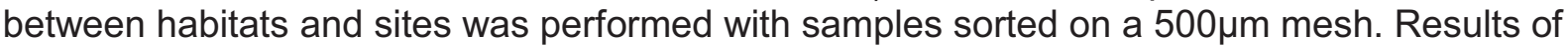
macrofauna density on $250 \mu \mathrm{m}$ are also presented, as usually done in our laboratory, to allow comparisons with most of the published studies. The samples taken for the taxonomic study were fixed in $4 \%$ buffered formalin for $48 \mathrm{~h}$ and transferred to $70 \%$ ethanol after 2 days.

Macrofauna was sorted, identified from phylum to family and counted in the laboratory (Ghent Univ. and IFREMER). For this study, polychaetes were identified to family level only for the $500 \mu \mathrm{m}$ fraction. Maldanidae specimens are only given as presence/absence and not counted because it was not possible to count head- and tail-less fragments. Due to their high proportion in the samples and because of their large size, meiofauna taxa with dominance of nematodes and copepods were counted and analysed together with sensus stricto macrofaunal taxa (Hessler et al. 1974).

\subsubsection{Environmental conditions}

Oxygen microsensors (Unisense) were used to measure oxygen concentration profiles in sediment cores sampled by the ROV Victor following the methods described in Rabouille et al. (2009). Undisturbed sediment cores were stored at $4^{\circ} \mathrm{C}$ and brought to laboratory temperature $\left(8-10^{\circ} \mathrm{C}\right)$ for measurements. Micro-profiles were quickly performed (within 2 h) with $\mathrm{O}_{2}$ microelectrodes mounted on a motor-driven micromanipulator interfaced to a computer (Revsbech et al. 1986). The Clark-type $\mathrm{O}_{2}$ microelectrodes had an internal reference and an outer tip diameter of 40 to $60 \mu \mathrm{m}$ (Unisense). The concentration of dissolved oxygen in the overlying water was measured using the Winkler method on three replicates to calibrate the microelectrodes.

The same cores were cut into 0.5 to $2 \mathrm{~cm}$ depth intervals to extract pore water. Each section was placed inside a $50 \mathrm{~mL}$ vial (Falcon tube) and centrifuged at $6000 \mathrm{rpm}$ for $20 \mathrm{~min}$. Porewater aliquots were acidified with $65 \%$ nitric acid (1/1000) for sulphate measurements and $\mathrm{ZnCl}_{2}$ was added to another aliquot $(1 \mathrm{~mL})$ immediately after pore-water extraction for sulphide analysis. The seawater samples analysed for sulphate were diluted in standard Milli-Q water (1/100). The analyses were carried out by ion chromatography on an isocratic system DX 120 (Dionex) with an automatic sampler Dionex AS 40. IAPSO samples of 
various salinities were used as standards. Sulphate concentrations were determined based on the ratios established by Millero (Millero 1996). Pore-water sulphide concentrations were analysed using standard photometric procedures (Cline 1969; Fonselius 1983).

High resolution sulphide and $\mathrm{pH}$ gradients were also measured with microsensors (Jeroschewski et al. 1996; De Beer et al. 1997) on other retrieved push cores during the expedition (Tab. 2). The microsensors were mounted on a motor-driven micromanipulator and data acquisition was performed with a DAQ-PAD 6015 and a computer. The surface of the sediment was determined with the help of a dissection microscope. During the measurements, the cores were kept in an aquarium with water cooled to in situ temperature $\left(1^{\circ} \mathrm{C}\right)$. A gentle air stream pointing at the water surface of the cores stirred the overlying water and assured the development of a distinct diffusive boundary layer.

The total sulphide $\left(\mathrm{H}_{2} \mathrm{~S}+\mathrm{HS}^{-}+\mathrm{S}^{2-}\right)$ was calculated from the $\mathrm{H}_{2} \mathrm{~S}$ concentrations and the local $\mathrm{pH}$ using equilibrium constants.

Methane concentrations were measured in water sampled just above the communities using static headspace gas chromatography (HSS-GC) on three replicates of $5 \mathrm{~mL}$ (Sarradin et al. 1996).

\subsubsection{Data analysis}

Faunal data from blade cores and suction samples from the same habitat were first grouped to estimate the total abundance by habitat. The sufficiencies of the taxonomic richness inventory and of the richness comparisons were assessed with individual-based rarefaction curves (Gotelli et al. 2001) first on macrofauna taxa and then on polychaete families for each habitat. Diversity indices were calculated for the polychaete community identified to the family level: taxonomic richness (S), Pielou's evenness (J), Shannon-Wiener (H) and Simpson's indexes. Maldanidae were removed from all indexes except for taxonomic richness. Then, average densities (number of individuals per $\mathrm{m}^{2}$ ) were estimated for each taxon in each habitat. Relative densities were also calculated to facilitate comparisons of community structure among habitats. Differences in habitat densities were tested using nonparametric tests (Wilcoxon-Man Whitney test $(n=2)$, Kruskal-Wallis test $(n>2))$ and a posthoc test: Berhens-Fisher (BF) non-parametric multiple comparisons.

Hellinger-transformed faunal data were used in all multivariate analyses. This transformation is used with linear methods such as principal component analysis (PCA) to preserve an ecologically meaningful measure of resemblance (Legendre et al. 2001). PCAs were performed to represent among-sample macrofaunal variation by habitat. Ward's hierarchical partitioning was computed to illustrate clusters of sample and to confront them with the PCA results.

A macrofauna analysis was performed with quantitative samples sieved on $500 \mu \mathrm{m}$ (Table 1). In the latter, as quantitative samples were sieved on $250 \mu \mathrm{m}$, results were also presented but without statistical analysis because of different sampling devices that unfortunately cannot be compared due to their differencies in efficiency. These samples increase the sampling effort on HMMV, and give an interesting complement to blade-core samples in some of the HMMV habitats and in the Storrega/Nyegga area. They also allowed comparison of macrofauna taxa sieved on 500 versus $250 \mu \mathrm{m}$. Moreover these results allowed comparison with other published seep macrofauna studies (Levin et al. 2007; Galéron et al. 2009; Menot et al. 2010; Ritt et al. 2010; Ritt et al. 2011). 
For non-quantitative suction samples taxa were scored based on their presence or absence, and were added to the comparison between seep sites, but they were not included in the statistical analyses.

Vertical fluxes of sulphide and sulphate were calculated from gradients in the sediment and corrected for porosity:

$\mathrm{J}_{\text {Sed }}=\phi \mathrm{D}_{\mathrm{Sed}} \frac{\mathrm{dc}}{\mathrm{dz}}$,

where $\phi$ is the porosity $(0.75)$ and $D_{\text {Sed }}$ is the diffusion coefficient in the sediment $\left(\mathrm{m}^{-2} \mathrm{~d}^{-1}\right)$, which was calculated according to Iversen and Jørgensen (1993) (Iversen et al. 1993):

$\mathrm{D}_{\text {Sed }}=\frac{\mathrm{D}}{1+3(1-\phi)}$

with a diffusion coefficient for sulfide as in Li and Gregory (1974) and for sulfate in Schutz and Zabel (2000).

All analyses were performed using the free open source $R$ Environment(R Developpement Core team 2008)The Vegan library was used for indexes, PCA and faunal data transformation (Oksanen et al. 2008), the NPMC (non-parametric-multiple comparisons) library was used for Behrens-Fisher non-parametric multiple comparisons (Helms et al. 2008) and the BiodiversityR library was used to draw rarefaction curves and circles of contribution (Kindt et al. 2005).

\section{Results}

\subsection{Macrofaunal community structure by habitat}

\subsubsection{Macrofauna $-\geq 500 \mu \mathrm{m}$ size fraction}

On HMMV, macrofauna $(\geq 500 \mu \mathrm{m})$ average densities were significantly different among habitats (Kruskal-Wallis, $X^{2}=10.09, p=0.039, B-F$ non-parametric multiple comparisons between all pairs significant with $p<0.05)$. Indeed, the lowest macrofauna density was located in the centre of the volcano (148 ind $\left.\mathrm{m}^{-2}\right)$, whereas intermediate values were found in the surrounding grey- and peripherical white- microbial mats (1000 ind. $\mathrm{m}^{-2}$ and 1352 ind. $\mathrm{m}^{-2}$ respectively). The highest faunal density was recorded in the $O$. haakonmosbiensis field $\left(67,741\right.$ ind. $\left.\mathrm{m}^{-2}\right)$ which was significantly higher than the density $\left(6389\right.$ ind. $\left.\mathrm{m}^{-2}\right)$ found in the siboglinid fields dominated by $S$. contortum (Table 3 ).

On the pockmarks of the Storegga and Nyegga area, macrofaunal densities associated with S. cf. contortum fields (11944 ind. $\mathrm{m}^{-2}$ and 5694 ind. $\mathrm{m}^{-2}$ respectively) were not significantly different from those of $S$. contortum fields on HMMV (Kruskal-Wallis, $X^{2}=3.11, p=0.38$,). Although colonised by $S$. cf. contortum, the pingo community sampled on $\mathrm{G} 11$ was denser than the other $S$. cf contortum field on the pockmarks (42 694 ind. $\mathrm{m}^{-2}$ ).

For the meiofaunal taxa, i.e., nematodes and copepods (Hessler et al. 1974; Dinet et al. 1985), we observed the same density pattern, increasing from the centre to the periphery of the seepage, at HMMV, with average densities significantly differing among habitats (Kruskal-Wallis: $X^{2}=10.10, p=0.039$ ). Post-hoc tests revealed significant differences in 
density among all pairwise comparisons (BF non-parametric multiple comparison between all pairs: $p<0.05)$. Finally, no significant difference in densities of fauna associated with $S$. contortum was observed between HMMV and Storegga slide (Cne5.6, G11) (Kruskal-Wallis: $X^{2}=6, p=0.42$ ).

Rarefaction curves based on macrofaunal taxa indicated that the sampling effort was insufficient to collect all taxa in the habitat (i.e., species were still accumulating) except on $O$. haakonmosbiensis and white microbial mats where curves were tending toward a plateau (Fig. 5). However, the $S$. contortum curve suggested that the taxonomic richness is the greatest in this habitat while for the white mat habitat, taxonomic richness was confirmed to be one of the poorest.

Relative macrofaunal density associated with the siboglinid tubeworms also varied according to the siboglinid species. In the fields dominated by $S$. contortum non siboglinid polychates (36.4\%), amphipods $(27.4 \%)$ and pycnogonids (pantopods) $(14.8 \%)$ were the dominant taxa, whereas gastropods (44.0\%) and tanaids (35.3\%) dominated in $O$ haakonmosbiensis fields, (Fig.6). White and grey microbial mats were not dominated by the same taxa: polychaetes $(88.9 \%)$ were dominant in the white mats, whereas gastropods $(88.9 \%)$ dominated the grey mats. The centre of the volcano was also dominated by polychaetes $(83.3 \%)$ although total densities were low (111 ind. $\left.\mathrm{m}^{-2}\right)$.

On the pockmarks of Storegga and Nyegga areas, polychaetes dominated the communities of $S$. cf contortum fields ( $34.6 \%$ to $69.0 \%$ ) except those of the pingo, which were dominated by gastropods ( $87.5 \%)$.

Considering meiofauna, copepods dominated the habitat in the centre of the mud volcano and nematodes represented $30 \%$ of inventoried taxa in the grey mats, and up to $10 \%$ in the white mats and in siboglinid fields (Fig. 6).

The PCA analysis suggests that samples are grouped by habitat rather than by site: HMMV $S$. contortum field samples could not be differentiated from those sampled in the same habitat of Nyegga pockmarks (Fig. 7). This analysis indicated the similarity of the macrofauna associated with $S$. cf. contortum patches in the pingo of Nyegga pockmark with those of $O$. haakonmosbiensis fields from the mud volcano and of the grey mats. These three habitats dominated by gastropods are separated by the first axis ( $49 \%$ of the variance) from others habitats dominated by polychaetes.

Ward's hierarchical partitioning showed that HMMV grey mats and Nyegga pingo are grouped with the $O$. haakonmosbiensis from HMMV. Similar patterns occurred for meiofaunal taxa. However, copepods became the major contributor to the axis 2, separating the centre of the volcano and the microbial mats from other habitats.

\subsubsection{Polychaeta $-\geq 500 \mu \mathrm{m}$ size fraction}

A total of 831 polychaetes belonging to 23 families were identified (Table 4). As for macrofauna $\geq 500 \mu \mathrm{m}$, accumulation curves based on polychaete taxa indicated in general incomplete sampling effort of polychaetes families. Nevertheless, the curves for the $O$. haakonmosbiensis habitat (HMMV) and S. cf contortum (Storrega) were tending toward a plateau (Fig. 8). Six families were dominant, with a density up to 300 ind. $\mathrm{m}^{-2}$ in at least one of the eight sampled habitats: Amphinomidae, Capitellidae, Dorvilleidae, Lumbrineridae, Paranoidae and Questidae (Table 4 and fig. 9). The center of the volcano and microbial mats are characterised by a low taxonomic richness ( 1 to 3 families), a low Shannon-Wiener index (0 to 0.2 ), a low equitability ( 0.2$)$ and a low Simpson's index (0 to 0.1$)$. This contrasts sharply 
with S. contortum habitats characterised by the highest taxonomic richness (10 to 16 families), a high Shannon-Wiener index (1.7 to 2.1) and high equitability and Simpson indices (0.8) (Table 4). O. haakonkmosbiensis and Pingo habitats had intermediate values (4 to 6 families). At the center of the volcano, Capitellidae was the only family present $(100 \%)$ and it represents $96 \%$ of the polychaetes in the white microbial-mat habitat. Combined with Dorvilleidae, those two families represented $95 \%$ of the polychaetes in the 0 . haakonmosbiensis (40\% and $55 \%$ respectively) fields and $68 \%$ in the Pingo habitats (46\% and $24 \%$, respectively). At $S$. contortum and S. cf. contortum habitats, Capitellidae and Dorvilleidae were absent or at very low density ( $0 \%$ to $26 \%$ for both families combined); other families occured quite regularly in these habitats.

On HMMV, average polychaete densities did not vary significantly among habitats (KruskalWallis, $X^{2}=7.7, p$ value $=0.10$ ) but tended to follow the same pattern as described in the previous paragraph for macrofauna $\geq 500 \mu \mathrm{m}$ with an increasing density from the center of the volcano to the siboglinid fields. The lowest densities were found in the center $\left(56\right.$ ind. $\left.\mathrm{m}^{-2}\right)$ and in grey microbial mats (56 ind. $\mathrm{m}^{-2}$ ), whereas the highest densities were found in Siboglinidae habitats (2278 ind $\mathrm{m}^{-2}$ at $S$. contortum field and 7417 ind $\mathrm{m}^{-2}$ at 0 . haakonsmosbiensis field). A remarkably high polychaete density was noticed in white microbial mats (1315 ind. $\mathrm{m}^{-2}$ ) contrasting with result found for macrofauna in the previous paragraph.Comparing all siboglinids habitats from HMMV, Storrega and Nyegga, polychaete densities did not vary significantly (Kruskal-Wallis, $X^{2}=5.0, p$ value $=0.17$ ), following the same patter as described in the previous paragraph for macrofauna $\geq 500 \mu \mathrm{m}$.

The PCA analysis on polychaetes confirms the pattern presented for macrofauna $\geq 500 \mu \mathrm{m}$ with a clustering by habitats rather than by site (Fig. 10). The first two axes explain $80 \%$ of the variance $(65 \%$ for the first axis and $15 \%$ for the second axis). Dorvilleidae mainly contributed to the first axis separating all $S$. contortum and $S$. cf. contortum habitats from other habitats. Capitellidae mainly contributed to the second axis and separated the center of the volcano and the white microbial mat from Pingo and $O$. haakonmosbiensis habitats. Paranoidae, Questidae, Lumbrineridae and Amphinomidae characterised Siboglinidae habitats (Fig. 10). Ward's hierarchical partitioning confirms the three groups revealed for macrofauna $\geq 500 \mu \mathrm{m}$.

\subsubsection{Macrofauna - $\geq 250 \mu \mathrm{m}$ size fraction}

On Håkon Mosby mud volcano, a total of 15226 indivuals were sampled with the minimum in the centre (316 individuals) and the maximum in 0 . haakonmosbiensis fields (5779 individuals) (Table 5). On average, $63 \%$ of these individuals were macrofauna sensus stricto.

As demonstrated for the fraction above $500 \mu \mathrm{m}$, the lowest density was located in the centre of the volcano and in the microbial mats (centre: 259 ind. $\mathrm{m}^{-2}$, grey mats: 2278 ind. $\mathrm{m}^{-2}$ and white mats: 3783 ind $\mathrm{m}^{-2}$ ). The highest was located in the siboglinid fields, especially in those colonized by $O$. haakonmosbiensis $\left(92,963\right.$ ind. $\left.\mathrm{m}^{-2}\right)$. Sediment adjacent to white microbial mats, not sampled for the macrofauna study $\geq 500 \mu \mathrm{m}$, showed intermediate densities between mats and $S$. contortum fieds (4992 ind. $\mathrm{m}^{-2}$, Table 5).

On the Storegga slide, 476 and 345 individuals were sampled on S. cf contortum fields of Nyegga and Storegga pockmarks respectively $(84 \%$ and $52 \%$ were macrofauna sensus stricto). These communities associated with $S$. cf. contortum were less dense compared to $S$. contortum on HMMV: 10,025 ind. $\mathrm{m}^{-2}$ (G11 pockmark) and 4475 ind. $\mathrm{m}^{-2}$ (Storegga pockmark: Cne5.6). 
For the meiofaunal taxa nematodes, copepods and ostracods (Hessler et al. 1974; Dinet et al. 1985), we observed the same density pattern as at HMMV, with densities increasing from the centre to the periphery of the seepage.

Relative macrofaunal density associated with the siboglinid tubeworms varied according to the siboglinid species. In S. contortum fields bivalves (33.9\%), non-siboglinid polychaetes $(25.7 \%)$ and isopods $(17.8 \%)$ were the dominant taxa, whereas gastropods $(50.9 \%)$ and tanaids $(30.1 \%)$ dominated in O haakonmosbiensis fields, although standard deviations were high among samples (Fig. 11). White and grey microbial mats were not dominated by the same taxa: polychaetes (93.2\%) were dominant in the white mats, whereas gastropods $(82.9 \%)$ dominated the grey mats. The sediment adjacent to white mats and the centre of the volcano were also dominated by polychaetes (respectively $55.4 \%$ and $64.3 \%$ ) but with very low densities in the centre (Table 5, Fig. 11).

Although only one sample was obtained on S. cf. contortum fields of Nyegga pockmark the taxonomic richness (Fig. 11) and composition were similar to those at HMMV (Fig. 11, Table 5). Nevertheless, the dominant taxa differed among sites. Indeed, bivalves were less abundant (11.7\% on G11 pockmark compared to $33.9 \%$ on HMMV) and communities were dominated by polychaetes $(30.4 \%)$ and isopods $(21.7 \%)$ on $\mathrm{G} 11$ pockmark rather than by bivalves and polychaetes as on HMMV. Taxonomic richness on $S$. cf. contortum fields of the Storegga pockmark seemed lower (but under-sampled) than on Nyegga and HMMV, and dominant taxa were different: polychaetes $(70.9 \%)$ and gastropods $(5.6 \%)$ dominated the community at the Storegga slide (Fig. 11). Non-quantitative sampling in the white mats of the pockmarks revealed similar taxa as in the HMMW white mats (polychaete gastropods and bivalves) (Table 6).

Considering meiofauna, nematods became the dominant taxa both in white microbial mats $(46.3 \%)$ and in S. contortum field of HMMV and Storrega pockmark (repectively $38.8 \%$ and $43.8 \%)$. In contrast, copepods dominated in the centre of the volcano (94.9\%), in the grey mats $(63.7 \%)$, and in sediment adjacent to white mats $(58.5 \%)$ (except one sample of adjacent sediment that was dominated by non-siboglinid polychaetes).

\subsection{Oxygen, sulphate and sulfide concentrations in sediment}

On HMMV, the oxygenated zone in the surface sediment was $7 \mathrm{~mm}$ thick in the $S$. contortum field. The sulphate flux was $1.73 \mathrm{~mol} \cdot \mathrm{m}^{-2} \cdot \mathrm{yr}^{-1}$ (Table 7 ). Weak variations in sulphide concentrations were observed from 0 to $7 \mathrm{~cm}$ below the seafloor $\left(3\right.$ to $7 \mu \mathrm{mol} \mathrm{L} \mathrm{L}^{-1}$ ), with two peaks at $1.5 \mathrm{~cm}$ and $4.5 \mathrm{~cm}$; sulphide concentration increased up to $20 \mu \mathrm{mol} \mathrm{L^{-1 }}$ and $30 \mu \mathrm{mol}$ $\mathrm{L}^{-1}$ at $4.75 \mathrm{~cm}$ depth (Fig. 12). Sulphide profiles in the centre were similar to the $S$. contortum field, with weak variation and a maximal sulphide concentration of $160 \mu \mathrm{mol} \mathrm{L}^{-1}$ at $2 \mathrm{~cm}$ depth. Highest sulphide concentrations were detected in the microbial mats, especially in the grey mats where maximum values varied between 9000 to $14000 \mu \mathrm{mol} \mathrm{L}^{-1}$ at $3.5 \mathrm{~cm}$ depth. In the white mats, the concentration maximum was found at about $2.5 \mathrm{~cm}$ depth $(2000$ to $6000 \mu \mathrm{mol} \mathrm{L}^{-1}$ ) (Fig. 12). Accordingly, the sulphide fluxes were higher in the grey and white mats $\left(8.2 \pm 1.3 \mathrm{~mol} \mathrm{~m}^{-2} \mathrm{yr}^{-1}\right.$ and $3.1 \pm 0.9 \mathrm{~mol} \mathrm{~m}^{-2} \mathrm{yr}^{-1}$, respectively) but 1 to 2 orders of magnitude lower in the centre and in $S$. contortum fields $\left(0.1 \mathrm{~mol} \mathrm{~m}^{-2} \mathrm{yr}^{-1}\right.$ and $0.02 \mathrm{~mol} \mathrm{~m}^{-2} \mathrm{yr}^{-1}$, respectively). This difference was significant (Kruskal-Wallis, $X^{2}=3.7, p=0.0 .5$ ).

On the G11 pockmark, the oxygen penetration depth was similar among the habitats, with slightly higher values in siboglinid fields than near gastropods and microbial filaments (Table 7 ), but this difference was not significant (Wilcoxon-Mann-Whitney $S$. cf. contortum vs. gastropods: $p=1$ ). The same patterns were found for the sulphate fluxes (Table 7) (WilcoxonMann-Whitney $S$. cf. contortum vs. gastropods: $p=1$ ). The sulphide concentrations just below 
the sediment-water interface were low $\left(<5 \mu \mathrm{mol} \mathrm{L} \mathrm{L}^{-1}\right)$ and no significant differences were observed among habitats (Wilcoxon-Mann-Whitney $S$. cf. contortum vs. gastropods: $p=1$ ). However, the sulphide distribution in the sediment varied among habitats. The highest and shallowest sulphide levels were measured in sediment inhabited by gastropod/microbial filaments, with a maximum of $1200 \mu \mathrm{mol} \mathrm{L}^{-1}$ (Fig. 12). Indeed, in S cf. contortum field, sulphide concentrations varied little with depth without any perceptible peaks (Fig. 12).

\subsection{Methane concentrations in water}

On HMMV, average methane concentrations varied among habitats with lower values above white microbial mats than on $S$. contortum fields (respectively $6 \mu \mathrm{mol} \mathrm{L}^{-1}$ and $15 \mu \mathrm{mol} \mathrm{L}^{-1}$ repectively) (Table 7). However, standard deviations indicated that concentrations varied greatly within a habitat. On the G11 pockmark, methane concentrations were below detection limit $\left(<0.1 \mu \mathrm{mol} \mathrm{L}{ }^{-1}\right)$ in all habitats (Table 7$)$.

\section{Discussion}

\subsection{Variability of community structure among habitats}

At the Norwegian cold seeps studied so far, two species of siboglinid polychaetes (Sclerolinum contortum and Oligobrachia haakonmosbiensis) colonise the periphery of seep areas and form vast tubeworm fields on Håkon Mosby mud volcano (Gebruk et al. 2003) and on the pockmarks of Storegga slide (Vanreusel et al. 2009; Meunier et al. 2010; Foucher et al. subm). The areas located closer to the fluid sources are covered by microbial mats that spread over large areas on the volcano (De Beer et al. 2006; Niemann et al. 2006b). In contrast to most other studied seep areas (Sibuet et al. 2002), no Vesicomyidae or Mytilidae bivalve aggregates have been observed at Norwegian seeps, with the exception of small dead vesicomyid shells at the Storrega slide pockmarks (Foucher et al. subm). Bivalves associated with siboglinids on HMMV are not large enough size to create a biogenic habitat as vesicomyids or mytilid do at other seep areas. Despite scale differences, the habitats at both volcano and pockmarks show concentric distribution around the fluid source. At HMMV, they are related to fluid flow as well as to geochemical and microbial gradients (Niemann et al. 2006b). Concentric distributions have also been observed on the Cascadia margin in the North-East Pacific (Sahling et al. 2002).

\subsubsection{Within seep macrofauna Variability}

Macrofaunal density varied among habitats at HMMV. Although the centre of the volcano showed the lowest density observed in 250 and $500 \mu \mathrm{m}$ sieve fractions, and the lowest taxonomic diversity, it was not totally devoid of fauna. However, faunal colonisation is clearly limited in this area and is likely greatly affected by mud flows. In the thick white microbial mats and in the adjacent sediment, the density of macrofauna was higher than in the centre but quite low compared to densities in siboglinid fields. The mean macrofaunal density in the $O$. haakonmosbiensis field (average 91,000 ind. $\mathrm{m}^{2}$, for macrofauna sensus stricto $\geq 300 \mu \mathrm{m}$ ) is the highest found yet at any cold-seep site. The previous maximum recorded density was in clam beds and microbial mats on the California margin (average of 34,000 ind. $\mathrm{m}^{2}$ and 23,000 ind. $\mathrm{m}^{2}$, respectively) (Levin et al. 2010). Nevertheless, whereas the white mats at HMMV had macrofaunal densities in the range of other cold-seep mats (Sahling et al. 2002; 
Levin et al. 2003; Levin et al. 2007; Levin et al. 2010), those estimated in grey mats were much lower (average 2200 ind. $\mathrm{m}^{2}$ ). The macrofaunal densities $(\geq 250 \mu \mathrm{m}$, without meiofaunal taxa), recorded on the Regab pockmark off Congo were the highest in proximity to mytilid beds (average 22,000 ind. $\mathrm{m}^{-2}$ ) (Menot et al. 2010), and this density is similar to those found in $S$. contortum fields of this study (without meiofaunal taxa). On the California continental slope, microbial mats have also been shown to harbor lower density than clam beds (Levin et al. 2003), but the difference is less pronounced than those between the faunal densities of mats and siboglinid fields on HMMV.

Community composition and taxonomic richness also varied among habitats on HMMV. Community variations were smaller within habitats than among them, except in the sediment adjacent to mats, which might be a more heterogeneous habitat. The influence of the type of habitats as defined by the dominant symbiont-bearing taxa or by microbial mats has already been observed at other cold-seep sites and this within-seep habitat heterogeneity contributes to enhancing regional diversity (Cordes et al. 2009; Cordes et al. 2010; Levin et al. 2010; Ritt et al. 2011). Moreover, our study also revealed variation in community structure among Siboglinidae species' fields as already observed for the Gulf of Mexico tubeworm thickets (Cordes et al. 2009). This difference evident in our data at class/order level as polychaetes and amphipods dominated $S$. contortum fields while gastropods and tanaids dominated $O$. haakonmobiensis ones. Previous non-quantitative studies on HMMV have also suggested dominance of polychaetes and bivalves in the $S$. contortum fields, but by caprellids and pycnogonids in O. haakonmobiensis (Gebruk et al. 2003).

Despite an incomplete sampling of macrofaunal taxa in both types of microbial mats, grey mats also seem to differ from white mats in terms of taxonomic composition, with a higher number of macrofaunal taxa, (as found in $O$. haakonmosbiensis fields), and dominance of gastropods instead of polychaetes in the white mats. Finally, all the microbial mat-associated macrofaunal communities described to date were always dominated by polychaetes (Sahling et al. 2002; Levin et al. 2007; Levin et al. 2010), while HMMV grey mats may be dominated by gastropods, when considering macrofauna sensus strict.

Because some polychaetes may have opportunistic feeding strategies (Fauchald et al. 1979) and high tolerance to hypoxia (Levin et al. 2003), polychaetes usually form an important part of the chemosynthetically associated fauna (Tunnicliffe 1991; Sahling et al. 2002; Menot et al. 2010; Ritt et al. 2010). At HMMV, polychaetes taxonomic richness included 14 families. This richness exceed those found by Ritt et al. (2010) in carbonate crusts from the Marmara Sea (6 families fraction $\geq 250 \mu \mathrm{m}$ ), and by Sahling et al. (2002) in the gas hydrate deposits from the NE Pacific Cascadia convergent margin (7 families in the $\geq 500 \mu \mathrm{m}$ fraction). However, the polychaetes in Norwegian seeps are less diverse at the familial level than in the Giant pockmark Regab from the Gulfe of Guinea (16 families, fraction > $500 \mu \mathrm{m}$ ) (Menot et al. 2010).

In the bare centre of HMMV, Capitellidae were the only polychaete representatives. This family includes genera, such as the cosmopolitan C. capitata complex, known to be able to live in reduced sulfidic and disturbed sediments, and in hydrothermal vents (Gamenick et al. 1998).

Whereas only one polychaete was found in the adjacent grey microbial mats (probably because we had a single sediment sample only), Capitellidae represents $96 \%$ of the polychaetes found in the surrounding white mats. The opportunistic Dorvilleidae and Questidae are the two other families present in the white mats. This is the first time Questidae have been recorded in seeps. In $O$. haakonmosbiensis tubeworm fields, where the associated macrofauna abundance is highest, the polychaete diversity is low: only 4 families still dominated by Capitellidae and Dorvilleidae. In contrast, polychaete diversity is 
maximal in $S$. contortum tubeworm fields, with 11 recorded families (Table 4), but their total abundance is $1 / 2$ that in $O$. haakonmosbiensis fields. Contrasting patterns in the two tubeworm fields, i.e., low diversity, with high abundance in $O$. haakonmosbiensis, and vice and versa in $S$. contortum fields, suggest that life conditions in $O$. haakonmosbiensis fields, close to the Beggiatoa mats, are harsh allowing only a few adapted families to survive, at high densities, probably due to a low interspecific competition. In contrast, life conditions appear milder in the contorted $S$. contortum fields where a greater number of families and species occur, but higher taxonomic richness may result in greater competition between the taxa, reducing the total polychaetes abundance. Amphinomidae and Questidae are the most abundant polychaete family associated with $S$. contortum tubeworm fields at HMMV (Tables 4 and 8). The presence of Amphinomidae in seeps is rare, but they have been recorded at vents and seamounts (Van Dover et al. 2001; Surugiu et al. 2008; Fabri et al. 2011). It is noteworthy that ampharetids and hesionids, which commonly are abundant at seeps (Sahling et al. 2002; Menot et al. 2010; Ritt et al. 2010), were absent at HMMV. The deposit-feeders Spionids and Cirratulids were also rare.

\subsubsection{Among seep macrofauna Variability}

On Storegga slide pockmarks, only Siboglinidae fields were quantitatively sampled. The same distribution pattern as on HMMV was observed, with fewer taxa near the fluid source (Table 6). The macrofaunal density in S. cf. contortum fields on pockmarks was lower than on HMMV, but the taxonomic composition was similar and clustered on the PCA, revealing higher similarity, by habitat type, rather than by site, at least at this taxonomic resolution. This is confirmed for polychaete families whose diversity indexes are quite homogeneous, among all S. contortum habitats with dominance by Amphinomidae, Questidae and occasionally Lumbrineridae, except for the "Pingo".

Site comparison with PCA revealed that samples from the same type of habitat, but from different sites seemed more similar than those from different habitats within the same site. For macrofauna sensus stricto $(500 \mu \mathrm{m}$ sieved samples), the first PCA axis separated the $S$. contortum fields on one sidefrom the $O$. haakonmobiensis fields and Nyegga Pingo on the other side (Fig. 7a). This figure shows that the factor pulling S. contortum fields to one side appears to be the polychaetes, whereas the presence of gastropods led the $O$. haakonmosbiensis fields and Nyegga pingo to the other side. In fact, the pingoes are small mounds made of mud and entangled $S$. contortum providing shelter for higher faunal density than other habitats. They reveal a low polychaete diversity dominated by families such as Capitellidae and Dorvilleidae and a strong dominance by gastropods, as found in $O$. haakonmosbiensis fields. The presence of gastropods may be explained by geochemical conditions more than by the presence of the siboglinid species.

\subsubsection{Relative contribution of meiofauna taxa}

Our study provides the first opportunity to compare macrofauna sensus lato among habitats and between cold-seep sites on the Norwegian margin, and to supplement our knowledge of HMMV's infauna previously restricted to meiofauna sensus lato (i.e. including macrofauna taxa) sieved on $32 \mu \mathrm{m}$ to $500 \mu \mathrm{m}$ (Soltwedel et al. 2005; Van Gaever et al. 2006; Van Gaever et al. 2009b). Although the large-sized nematodes and copepods are not including in macrofauna taxa sensus stricto in deep-sea sediments (Hessler et al. 1974; Dinet et al. 1985) because they are generally not very abundant on mesh sizes greater than $250 \mu \mathrm{m}$, they are nevertheless abundant at seeps (Olu et al. 1997; Van Gaever et al. 2009a) and may 
contribute significantly to faunal abundance for sieves on $250 \mu \mathrm{m}$ and even on $500 \mu \mathrm{m}$ (Table 8).

Both on HMMV and pockmarks we observed high contributions of nematods and copepods to macrofaunal fractions. They were often dominant in $250 \mu \mathrm{m}$ fractions, although with variable contributions between habitats (14-96\%), and also present in $500 \mu \mathrm{m}$ fractions (0-44 $\%)$. Less abundant meiofaunal taxa included acarians and ostracods that, like cumaceans, disappeared between $250 \mu \mathrm{m}$ and $500 \mu \mathrm{m}$ fractions, also highlighting differences between sieve sizes.

Interestingly, meio- and macrofauna within a size fraction did not follow the same patterns of density relative to habitats (Table 8). Macrofauna taxa dominated in $250 \mu \mathrm{m}$ fractions in siboglinid habitats but meiofauna taxa dominated in mats and in the centre habitat. In this latter habitat meiofaunal dominance $(96 \%$ on $250 \mu \mathrm{m})$ was due to the abundance of copepods as reported by Van Gaever et al. (2006), while in white mats (250 $\mu \mathrm{m}$ fraction) and $S$. contortum habitats, nematodes led to meiofaunal dominance. Differences in relative abundance of meiofaunal and macrofaunal taxa may be related to low predation pressure by the macrofauna in the harshest habitats, or to better adaptation of dominant meiofauna taxa. Indeed, no predator of the dominant nematode Halomonhystera disjuncta which was very abundant in Beggiatoa mats, has been identified by stable isotope studies ((Van Gaever et al. 2006; Decker et al. 2010). Moreover, this species may have increased competitiveness due to adaptations to environmental stresses, such as ovoviviparous reproduction (Van Gaever et al. 2006; Van Gaever et al. 2009b).

\subsection{Influence of habitat chemical heterogeneity on community patterns}

Geochemical gradients at seeps have been demonstrated to drive the distribution of the symbiotic structuring fauna (Sahling et al. 2002; Olu-Le Roy et al. 2007), but also the associated macrofaunal community structure (Sahling et al. 2002; Levin et al. 2003; Sahling et al. 2003; Bergquist et al. 2005; Cordes et al. 2005; Olu-Le Roy et al. 2007). On HMMV, the biogenic habitats used to define the faunal sampling strategy have been related to differences in geochemical and microbial processes. The central area is subjected to upward advection of mud with high fluid flow (Kaul et al. 2006) by oxygen depletion $2 \mathrm{~mm}$ below the seafloor (De Beer et al. 2006), by high temperatures in the sediment (Feseker et al. 2008) and by high methane concentrations above the sediment colonised by metanotrophic bacteria (Niemann et al. 2006b). These conditions seem to create a hostile environment with low faunal densities and taxonomic richness, dominated by epibenthic taxa, including adult copepods and nauplii larvae (Van Gaever et al. 2006). This is in agreement with seafloor images showing very rare megafauna in this area described as azoic (Gebruk et al. 2003), which suggested a role for high temperatures in subsurface sediments $\left(11^{\circ} \mathrm{C}\right.$ at $\left.30 \mathrm{~cm}\right)$. Unusual temperatures were confirmed by further in situ measurements with $16^{\circ} \mathrm{C}$ at $30 \mathrm{~cm}$ depth in the central area of HMMV (Feseker et al. 2008). Low densities of both macrofaunal and meiofaunal may also result from the high fluid flow and instability in the central part of the volcano, where mud flows are expelled.

The habitat populated by white microbial mats also experiences high fluid flow (De Beer et al. 2006; Kaul et al. 2006), but is shows lower methane concentration above the sediment (Niemann et al. 2006b) and a higher sulphide flux than in the mud volcano centre, caused by high rates of anaerobic oxidation of methane with sulphate in the sediment (Tab. 6) (De Beer et al. 2006; Niemann et al. 2006a; Lichtschlag et al. 2010). However, the oxygen penetration depth in microbial mats is similar to those in the central area (De Beer et al. 2006). This could lead to the dominance of a few taxa that are adapted to low oxygen levels $(0.05 \mathrm{mmol}$ $\mathrm{L}^{-1}$ at the sediment-water interface) and to high sulphide fluxes and concentrations near the 
sediment-water interface $\left(2 \mathrm{mmol} \mathrm{\textrm {L } ^ { - 1 }}\right.$ at about $0.5 \mathrm{~cm}$ depth). Capitellid polychaetes abundant on microbial mats are non-selective feeder occasionally recorded at seep, and the dorvilleids are known to thrive in sulphide-rich environments (Sahling et al. 2002; Levin et al. 2003). Gastropods sampled on microbial mats and in O. haakonmobiensis fields have been identified as Rissoidae (A. Warén pers.com.), a family also found in a seep mussel bed with high sulfide and low oxygen levels (Bergquist et al. 2005).

In contrast, the high macrofaunal densities and taxonomic richness in the siboglinid fields located at the periphery of the mud volcano might be facilitated by a lower fluid flow (Kaul et al. 2006), and lower sulphide levels (or sulfide peaks deeper in the sediment) with deeper oxygen penetration depth $(7-10 \mathrm{~mm})$ (This study, De Beer et al. 2006). The sulphide profile in $S$. contortum fields indicates that the sulphide concentrations are low within the upper $7 \mathrm{~cm}$ of the sediment (Fig. 11). The lower sulphide flux in the upper sediment layer of the $S$. contortum fields is caused by AOM (anaerobic methane oxidation) occuring deeper (Niemann et al. 2006a), due to the active downward transport of sulphate-rich seawater by pumping activity of the siboglinids (De Beer et al. 2006). High densities of Amphinomidae, Questidae and Paraonidae in this habitat may be favoured by less extreme conditions than in the cental,, microbial mat and $O$. haakonmosbiensis habitats. Amphinomidae are not often recorded at seeps but their enlarged branchial system may provide a good opportunity to colonize anoxic areas such as chemosynthetical environements. Paraonidae are found at high densities at eutrophic and mesotrophic deep-sea sites (Cosson-Sarradin et al. 1998) and dominate at oxygen minimum zones (Levin et al. 2003), but are often considerated rare or uncommum in seep areas. However paranoids have recently been found at high densities at the Regab pockmark (Menot et al. 2010) and are not negligeable in this study. Polychaete families in the $S$. contortum habitat are therefore appear either to be sulfide tolerant or opportunistic in their feeding strategy (Fauchald et al. 1979). The denser assemblages of macrofauna observed in the $O$. haakonmosbiensis fields compared to $S$. contortum fields may be favoured by intermediate conditions, because they are closer to the active area of the volcano than S. contortum fields (Fig. 3). However, the physico-chemical conditions have not yet been measured in this area. $O$. haakonmosbiensis fields are located in an area where gas bubbles have been recorded above the seafloor, probably resulting in different sediment chemistry than the gas-saturated mud flows of the centre (Foucher, pers. com). This may create very good conditions for great biological biomass. The Dorvilleidae that dominate this habitat, together with the Capitellidae, are sulphide-tolerant and often colonize heavily polluted area often at high densities (Fauchald and Jumars, 1979). The $O$. haakonmosbiensis fields may provide a habitat, with reduced competition and predation for these polychaetes families (Levin et al. 2003).

The distribution of macrofauna associated with the different habitats of HMMV is therefore likely driven by different sulphide concentration and fluxes that vary along the fluid flow gradient from the active centre to the $S$. contortum fields at the periphery. This study highlights the differences in macrofauna and meiofauna response to environmental variables: the ratio of meiofauna to macrofauna in $250 \mu \mathrm{m}$ fractions is higher in the central area, exposed to variable fluid flow, and in the highly sulfidic and oxygen-poor habitats (white and grey mats and adjacent sediment), than in siboglinid fields, where the macrofauna is abundant and highly diverse (high taxonomic richness and high beta diversity among samples).

On Storegga slide pockmarks, a gradient of taxonomic richness was also suggested from the fluid source within mats ( 1 to 3 taxa), to the siboglinid fields (>10 taxa), albeit at smaller scales than on HMMV. The chemical characterisation of both habitats (Table 7) similarly revealed gradients from the seep source to the peripheral $S$. contortum fields. Sulphide profiles (Fig. 12) showed a peak closer to the sediment surface with higher concentrations below microbial mats and gastropods than below $S$. cf. contortum fields. These profiles are 
similar to those below Cascadia microbial mats and solemyid bivalve fields, respectively, which also differ in taxonomic richness and composition (Sahling et al. 2002).

Lower sulphide levels, deeper oxygen penetration, higher stability of the substratum and the proximity of surrounding background sediments likely favours macrofaunal richness in siboglinid fields of both HMMV and Storrega pockmarks. Nonetheless the three dimensional structure of the siboglinid tubeworms may also play a role in providing a suitable biogenic habitat and many ecological niches for a variety of macrofauna taxa. This is particularly evident for the curved $S$. contortum species compared to the straight $O$. haakonmobiensis. $S$. contortum (and to a lesser extent $O$. haakonmosbiensis) might thus be ecosystem engineers (Jones et al. 1994) building habitat that may provide refuges from predation, competition and physical as well as chemical stresses. In addition, the tubworms may provide important food resources or nursery and spawning habitats, similar to the reef-building tubeworm Lanice conchilega in coastal areas (Zuhlke et al. 1998; Rabaut et al. 2007; Rabaut et al. 2009).

\section{Conclusions}

In this first study of the macrofaunal community structure of six habitat types in Norwegian seeps, we evidenced high $\beta$ diversity, even at high taxonomic levels, confirming the relationships between habitat heterogeneity and biodiversity at seeps. Fluid flow and sulphide and oxygen gradients appeared to be important structuring factors, but engineering species (tubeworms) as well as other biotic factors may influence the richness of associated fauna. We also found high variability in macrofaunal community structure and composition among habitats structured by different siboglinid species, or microbial mats. The highest macrofaunal densities, ever found in a cold-seep area, were observed in Siboglinidae Oligobrachia haakonmosbiensis fields located along the fluid flow gradient on HMMV, while the highest taxonomic richness was observed in the peripherical fields of the tubeworm Sclerolinum contortum. Meiofaunal taxa were important in both $250 \mu \mathrm{m}$ and $500 \mu \mathrm{m}$ size fractions, stemming from their large size and great abundance at seeps. Finally, we find that geochemical and biotic habitat gradients, rather than regional or bathymetric processes, appear to be the main driving forces behind macrofaunal community structure along the Norwegian margin.

\section{Acknowledgements}

We are grateful to the chief scientists and project leader of the VICKING cruise $(\mathrm{H}$. Nouzé, J.P. Foucher) and of the ARK-XXII (M. Klages) cruise; to the captains and crews of the R/V Pourquoi Pas? and R/N Polarstern and the crews of Victor 6000 and Quest 4000. We thank M.-C. Fabri, P. Noël for their help on board P. Pignet for sulphate measurements and $O$. Mouchel for sorting samples. Marie Morineaux work was supported by the French ANR program DeepOases. We thank Anders Warén for gastropod identification and M. Hovland for the map of Nyegga pockmarks G11 and G12. The English was professionally edited by Carolyn Engel-Gautier. Anna Lichtschlag study was supported by the GEOTECHNOLOGIEN project MUMM II (03G0608C) funded by the German Ministry of Education and Research (BMBF) and German Research Foundation (DFG). The VICKING and ARK-XXII cruises were part of the FP6 European programme HERMES (GOCE-CT-2005-511234-1) and FP7 HERMIONE (ENV/2008/1/226354). 


\section{References}

Bayon, G., L. Loncke, S. Dupré, J.C. Caprais, E. Ducassou, S. Duperron, J. Etoubleau, J.P. Foucher, Y. Fouquet, S. Gontharet, G.M. Henderson, C. Huguen, I. Klaucke, J. Mascle, S. Migeon, K. Olu-Le Roy, H. Ondréas, C. Pierre, M. Sibuet, A. Stadnitskaia, J. Woodside (2009) Multi-disciplinary investigation of fluid seepage on an unstable margin: The case of the Central Nile deep sea fan. Marine Geology, 261(1-4), 92-104.

Bergquist, D.C., J.P. Andras, T. McNelis, S. Howlett, M.J. van Horn, C.R. Fisher (2003a) Succession in Gulf of Mexico Cold Seep vestimentiferan aggregations: the importance of spatial variability. P. S. Z. N. I: Marine Ecology, 24(1), 31-44.

Bergquist, D.C., C. Fleckenstein, J. Knisel, B. Begley, I.R. MacDonald, C.R. Fisher (2005) Variations in seep mussel bed communities along physical and chemical environmental gradients. Marine Ecology Progress Series, 293, 99-108.

Bergquist, D.C., T. Ward, E.E. Cordes, T. McNelis, S. Howlett, R. Kosoff, S. Hourdez, R. Carney, C.R. Fisher (2003b) Community structure of vestimentiferan-generated habitat islands from Gulf of Mexico cold seeps. Journal of Experimental Marine Biology and Ecology, 289, 197-222.

Brown, K., G.K. Westbrook (1988) Mud diapirism and subcretion in the Barbados ridge accretionary complex: the role of fluids in accretionary processes. Tectonics, 7(3), 613-640.

Cline, J.D. (1969) Spectrophotometric determinations of hydrogen sulfide in natural waters. Limnology and Oceanography, 14(3), 454-458.

Cordes, E.E., D.C. Bergquist, C. Fisher (2009) Macro-Ecology of Gulf of Mexico Cold Seeps. Annuual Review of Marine Sciences, 1, 143-168.

Cordes, E.E., M.R. Cunha, J. Galéron, C. Mora, K. Olu - Le Roy, M. Sibuet, S. Van Gaever, A. Vanreusel, L.A. Levin (2010) The influence of geological, geochemical, and biogenic habitat heterogeneity on seep biodiversity. Marine Ecology, 31(1), 51-65.

Cordes, E.E., S. Hourdez, B.L. Predmore, M.L. Redding, C.R. Fisher (2005) Succession of hydrocarbon seep communities associated with the long-lived foundation species Lamellibrachia luymesi. Marine Ecology Progress Series, 305, 17-29.

Cosson-Sarradin, N., M. Sibuet, G. Paterson, A. Vangriesheim (1998) Polychaete diversity at tropical Atlantic deep-sea sites: environmental effects. . Marine Ecology Progress Series, $165,173-185$.

De Beer, D., A. Glud, E. Epping, K. M. (1997) A fast responding CO2 microelectrode for profiling sediments, microbial mats and biofilms. Limnology and Oceanography, 42, 15901600.

De Beer, D., E. Sauter, H. Niemann, N. Kaul, J.P. Foucher, U. Witte, M. Schlüter, A. Boetius (2006) In situ fluxes and zonation of microbial activity in surface sediments of the Hâkon Mosby mud volcano. Limnology and Oceanography, 51(3), 1315-1331.

Decker, C., K. Olu (2010) Does macrofauna nutrition vary among habitats at Håkon Mosby Mud Volcano? Cahiers de Biologie Marine, 51(4), 361-367. 
Dinet, A., D. Desbruyères, A. Khripounoff (1985) Abondances des peuplements macro- et meio-benthiques : répartition et stratégie d'échantillonnage. In: L. Laubier \& C. Monniot (Eds). Peuplements profonds du golfe de Gascogne : campagnes BIOGAS. IFREMER Srvice Documentation-Publications, Brest: 121-142.

Fabri , M.C., A. Bargain, P. Briand, A. Gebruk, Y. Fouquet, M. Morineaux, D. Desbruyères (2011) The hydrothermal vent community of a new deep-sea field, Ashadze-1, $12858^{\prime} \mathrm{N}$ on the Mid-Atlantic Ridge. Journal of Marine Biological Association of The United Kingdom, 91(1), 1-13.

Fauchald, K., P.A. Jumars (1979) The diet of worms: A study of polychaete feeding guilds. Oceanogr. Mar. Biol. Ann. Rev., 17, 193-284.

Felden, J., F. Wenzhöfer, T. Feseker, A. Boetius (2010) Transport and consumption of oxygen and methane in different habitats of the Hakon Mosby Mud Volcano (HMMV). Limnology and Oceanography, 55(6), 2366-2380.

Feseker, T., J.P. Foucher, F. Harmegnies (2008) Fluid flow or mud eruptions? Sediment temperature distributions on Håkon Mosby mud volcano, SW Barents Sea slope. Marine Geology, 247(3-4), 194-207.

Fonselius, S.H. (1983) Determination of hydrogen sulfide. In: K. Grasshof (Ed). Methods of sea-water analysis. Verlag Chemie, Kiel: 73-84.

Foucher, J.P., C. Pierre, C. Decker, L.R. Rufine, S. Ker, G. Westbrook, K. Olu - Le Roy, J.P. Donval, J.L. Charlou (subm) Seabed observations of methane seepage at Nyegga chimneys off mid-Norway. Results from the Vicking cruise (2006): . Marine Geology.

Foucher, J.P., G. Westbrook, A. Boetius, S. Ceramicola, S. Dupré, A. Mascle, J. Mienert, O. Pfannkuche, C. Pierre, D. Praeg (2009) Structure and drivers of cold-seep ecosystems. Oceanography, 22(1), 92-109.

Galéron, J., L. Menot, N. Renaud, P. Crassous, A. Khripounoff, C. Treignier, M. Sibuet (2009) Spatial and temporal patterns of benthic macrofaunal communities on the deep continental margin in the Gulf of Guinea. Deep Sea Research Part II: Topical Studies in Oceanography, 56(23), 2299-2312.

Gamenick, I., M. Abbiati, O. Giere (1998). Field distribution and sulphide tolerance of Capitella capitata (Annelida: Polychaeta) around shallow water hydrothermal vents off Milos (Aegean Sea). A new sibling species? Marine Biology, 130, 447-453.

Gebruk, A., E.M. Krylova, A. Lein, G.M. Vinogradov, E. Anderson, N.V. Pimenov, G.A. Cherkashev, K. Crane (2003) Methane seep community of the Hakon Mosby mud volcano the Norvegian Sea: composition and trophic aspects. Sarsia, 88(6), 394-403.

Gotelli, N.J., R.K. Colwell (2001) Quantifying biodiversity: procedures and pitfalls inn the measurement and comparison of species richness. Ecology Letters, 4, 379-391.

Helms, J., U. Munzel (2008) Nonparametric Multiple Comparisons. CRAN.

Hessler, R.R., P.A. Jumars (1974) Abyssal community analysis from replicate box; cores in the central North Pacific. Deep Sea Research and Oceanographic Abstracts, 21(3), 185-209.

Hovland, M., H. Svensen, C.F. Forsberg, H. Johansen, C. Fichler, J.H. Fossa, R. Jonsson, $\mathrm{H}$. Rueslatten (2005) Complex pockmarks with carbonate-ridges off mid-Norway: Products of sediment degassing. Marine Geology, 218(1-4), 191. 
Hovland, M., S. Svensen (2006) Submarine pingoes: Indicators of shallow gas hydrates in a pockmark at Nyegga, Norwegian Sea. Marine Geology, 228, 15-23.

Hustoft, S., J. Mienert, S. Buenz, H. Nouze (2007) High-resolution 3D-seismic data indicate focussed fluid migration pathways above polygonal fault systems of the mid-Norwegian margin. Marine Geology, 245(1-4), 89-106.

Iversen, N., B.B. Jørgensen (1993) Diffusion coefficients of sulfate and methane in marine sediments: Influence of porosity. Geochimica et Cosmochimica Acta, 57, 571-578.

Jerosch, K., A. Lüdtke, M. Schlüter, G.T. Ioannidis (2007a) Automatic content-based analysis of georeferenced image data: Detection of Beggiatota mats in seafloor video mosaics from the Haakon Mosby Mud Volcano. Computer and Geosciences, 33, 202-218.

Jerosch, K., M. Schlüter, J.P. Foucher, A.G. Allais, M. Klages, C. Edy (2007b) Spatial distribution of mud flows, chemoautotrophic communities, and biogeochemical habitats at Hakon Mosby Mud Volcano.

Jeroschewski, P., C. Steuckart, M. Kühl (1996) An amperometric microsensor for the determination of H2S in aquatic environment. Anal. Chem., 68, 4351-4357.

Jones, C.G., J.H. Lawton, M. Shachak (1994) Organisms as ecosystem engineers. Oikos, 69, 373-386.

Kaul, N., J.P. Foucher, M. Heeseman (2006) Estimating mud expulsion rates from temperature measurements on Hakon Mosby mud Volcano, SW Brents Sea. Marine Geology, 229, 1-14.

Kindt, R., R. Coe (2005). Tree diversity analysis. A manual and software for common statistical methods for ecological and biodiversity studies. World Agroforestry Centre (ICRAF), Nairobi.

Le Pichon, X., J.P. Foucher, J. Boulègue, P. Henry, S. Lallemant, M. Benedetti, F. Avedik, A. Mariotti (1990) Mud volcano field seaward of the Barbados accretionary complex: a submersible survey. Journal of Geophysical Research, B, 95(B6), 8931-8943.

Legendre, P., E.D. Gallagher (2001) Ecologically meaningful transformations for ordination of species data. Oecologia, 129, 271-280.

Levin, L.A. (2005) Ecology of cold seep sediments: interactions of fauna with flow, chemistry and microbes. Oceanography and Marine Biology Annual Review, 43, 1-46.

Levin, L.A., G.F. Mendoza (2007) Community structure and nutrition of deep methane-seep macrobenthos from the North Pacific (Aleutian) Margin and the Gulf of Mexico (Florida Escarpment). Marine Ecology-an Evolutionary Perspective, 28(1), 131-151.

Levin, L.A., G.F. Mendoza, J.P. Gonzalez, A.R. Thurber, E.E. Cordes (2010) Diversity of bathyal macrofauna on the northeastern Pacific margin: the influence of methane seeps and oxygen minimum zones. Marine Ecology, 31(1), 94-110.

Levin, L.A., W. Ziebis, G.F. Mendoza, V.A. Growney, M.D. Tryon, C. Mahn, J.M. Gieskes, A.E. Rathburn (2003) Spatial heterogeneity of macrofauna at northern California methane seeps: influence of sulfide concentration and fluid flow. Marine Ecology Progress Series, 265, 123-139. 
Li, Y.H., S. Gregory (1974) Diffusion of ions in sea water and in deep-sea sediments. Geochimica et Cosmochimica Acta, 38, 703-714.

Lichtschlag, A., J. Felden, V. Brüchert, A. Boetius, D. De Beer (2010) Geochemical processes and chemosynthetic primary production in different thiotrophic mats of the Hakon Mosby Mud Volcano (Barents Sea). Limnology and Oceanography, 56(2), 931-949.

Lösekann, T., A. Robador, H. Niemann, K. Knittel, A. Boetius, N. Dubilier (2008) Endosymbioses between bacteria and deep-sea siboglinid tubeworms from an Arctic Cold Seep (Haakon Mosby Mud Volcano, Barents Sea). Environmental Microbiology, 10(12), 3237-3254.

Menot, L., J. Galéron, K. Olu, J.C. Caprais, P. Crassous, A. Khripounoff, M. Sibuet (2010) Spatial heterogeneity of macro-infaunal communities in and near a giant pockmark area in the deep Gulf of Guinea. Marine Ecology, 31(1), 78-93.

Meunier, C., A. Andersen, M. Bruneaux, D. Le Guen, P. Terrier, E. Leize-Wagner, F. Zal (2010) Structural characterization of hemoglobins from Monilifera and Frenulata tubeworms (Siboglinids): First discovery of giant hexagonal-bilayer hemoglobin in the former "Pogonophora" group. Comparative Biochemistry and Physiology, Part A, 155(1), 41-48.

Milkov, A., P. Vogt, K. Crane, A. Lein, R. Sassen, G. Cherkashev (2004) Geological, geochemical, and microbial processes at the hydrate-bearing Hakon Mosby Mud Volcano: a review. Chemical Geology, 205, 347-366.

Millero, F.J. (1996). Chemical oceanography. CRC Press, Boca Raton, New York, London, Tokyo: 469 pp.

Niemann, H., J. Duarte, C. Hensen, E. Omoregie, V.H. Magalhaes, M. Elvert, L.M. Pinheiro, A. Kopf, A. Boetius (2006a) Microbial methane turnover at mud volcanoes of the Gulfe of Cadiz. Geochimica et Cosmochimica Acta, 70, 5336-5355.

Niemann, H., T. Losekann, D. de Beer, M. Elvert, T. Nadalig, K. Knittel, R. Amann, E.J. Sauter, M. Schluter, M. Klages, J.P. Foucher, A. Boetius (2006b) Novel microbial communities of the Haakon Mosby mud volcano and their role as a methane sink. Nature, 443(7113), 854-858.

Oksanen, J., R. Kindt, P. Legendre, B. O'Hara, G.L. Simpson, P. Solymos, M. Henry, H. Stevens, H. Wagner (2008) Vegan: Community Ecology Package. R package version 1.15-1. http://cran.r-project.org/

Olu-Le Roy, K., J.C. Caprais, A. Fifis, M.C. Fabri, J. Galéron, H. Budzinski, K. Le Ménach, A. Khripounoff, H. Ondréas, M. Sibuet (2007) Cold seep assemblages on a giant pockmark off West Africa: spatial patterns and environmental control. Marine Ecology, 28, 115-130.

Olu-Le Roy, K., M. Sibuet, A. Fiala-Médioni, S. Gofas, C. Salas, A. Mariotti, J.P. Foucher, J. Woodside (2004) Cold seep communities in the deep eastern Mediterranean Sea: composition, symbiosis and spatial distribution on mud volcanoes. Deep-Sea Research I, 51, 1915-1936.

Olu, K., F. Lance, M. Sibuet, P. Henry, A. Fiala-Médioni, A. Dinet (1997) Cold seep communities as indicators of fluid expulsion patterns through mud volcanoes seaward of the Barbados accretionary prism. Deep-Sea Research II, 44(5), 811-841. 
Paull, C.K., B. Hecker, R. Commeau, R.P. Freeman-Lynde, C. Neumann, W.P. Corso, S. Golubic, J.E. Hook, E. Sikes, J. Curray (1984) Biological communities at the Florida escarpment resemble hydrothermal vent taxa. Science, 226, 965-967.

Paull, C.K., W. Ussler, W. Holbrook, T.M. Hill, R. Keaten, J. Mienert, H. Haflidason, J.E. Johnson, W.J. Winters, T.D. Lorenson (2008) Origin of pockmarks and chimney structures on the flanks of the Storegga Slide, offshore Norway. Geo-Marine Letters 28(1), 43-51.

R Developpement Core team (2008) R: A language and environment for statistical computing. R Foundation for Statistical Computing, Vienna, Austria.

Rabaut, M., K. Guilini, G. Van Hoey, M. Vincx, S. Degraer (2007) A bio-engineered softbottom environment: The impact of Lanice conchilega on the benthic species-specific densities and community structure. Estuarine, Coastal and Shelf Science, 75, 525-536.

Rabaut, M., M. Vincx, S. Degraer (2009) Do Lanice conchilega (sandmason) aggregations classify as reefs? Quantifying habitat modifying effects. Helgol Mar Res, 63, 37-46.

Rabouille, C., J.C. Caprais, B. Lansard, P. Crassous, K. Dedieu, J.L. Reyss, A. Khripounoff (2009) Organic matter budget in the Southeast Atlantic continental margin close to the Congo Canyon: In situ measurements of sediment oxygen consumption. Deep Sea Research Part II: Topical Studies in Oceanography, 56(23), 2223-2238.

Revsbech, N., B.B. Jorgensen (1986) Micoelectrodes - their use in microbial ecology. Advances in microbial ecology, 9, 293-352.

Ritt, B., C. Pierre, O. Gauthier, F. WenzhÃđfer, A. Boetius, J. Sarrazin (2011) Diversity and distribution of cold-seep fauna associated with different geological and environmental settings at mud volcanoes and pockmarks of the Nile Deep-Sea Fan. Marine Biology, 158(6), 1187-1210.

Ritt, B., J. Sarrazin, J.C. Caprais, P. Noël, O. Gauthier, C. Pierre, P. Henry, D. Desbruyères (2010) First insights into the structure and environmental setting of cold-seep communities in the Marmara Sea. Deep Sea Research, 57, 1120-1136.

Sahling, H., S.V. Galkin, A. Salyuk, J. Greinert, H. Foerstel, D. Piepenburg, E. Suess (2003) Depth-related structure and ecological significance of cold-seep communities--a case study from the Sea of Okhotsk. Deep Sea Research Part I: Oceanographic Research Papers, 50(12), 1391-1409.

Sahling, H., D. Rickert, R.W. Lee, P. Linke, E. Suess (2002) Macrofaunal community structure and sulfide flux at gas hydrate deposits from the Cascadia convergent margin, NE Pacific. Marine Ecology Progress Series, 231, 121-138.

Sarradin, P.-M., J.C. Caprais (1996) Analysis of dissolved gases by headspace sampling, gas chromatography with columns and detectors commutation. Preliminary results. Analytical Communications, 33, 371-373.

Sauter, E.J., S.I. Muyakshin, J.-L. Charlou, M. Schlüter, A. Boetius, K. Jerosch, E. Damm, J.P. Foucher, M. Klages (2006) Methane discharge from a deep-sea submarine mud volcano into the upper water column by gas hydrate-coated methane bubbles. Earth and Planetary Science Letters, 243(3-4), 354-365.

Schulz, H.D., M. Zabel (2000). Marine Geochemistry. Springer, New-York: 453 pp. 
Sibuet, M., K. Olu-Le Roy (2002) Cold Seep Communities on Continental Margins: Structure and Quantitative Distribution Relative to Geological and Fluid Venting Patterns. In: D.B. G. Wefer, D. Hebbeln, B.B. Jorgensen, T. Van Weering (Ed). Ocean Margin Systems. Springer Verlag, Berlin: 235-251.

Sibuet, M., K. Olu (1998) Biogeography, biodiversity and fluid dependence of deep-sea coldseep communities at active and passive margins. Deep-Sea Research II, 45, 517-567.

Simpson, G.G. (1964) Species density of North American recent mammals. Systematic zoologie, 13, 57-73.

Smirnov, R.V. (2000) Two new species of pogonophora from the arctique mud volcano off norwestern Norway. Sarsia, 85, 141-150.

Soltwedel, T., D. Portnova, I. Kolar, V. Mokievsky, I. Schewe (2005) The small-sized benthic biota of the Hakon Mosby Mud Volcano (SW Barents Sea slope). Journal of Marine Systems, 55(3-4), 271.

Suess, E., B. Carson, S.D. Ritger, J.C. Moore, M.L. Jones, L.D. Kulm, G.R. Cochrane (1985) Biological communities at vent sites along the subduction zone off Oregon. Bulletin of the Biological Society of Washington, 6, 475-484.

Surugiu, V., J.C. Dauvin, P. Gillet, T. Ruellet (2008) Can Seamounts Provide A Good Habitat for Annelida, Polychaeta ? Example of the North-Eastern Atlantic Seamounts. Deep Sea Research, 55, 1515-1531.

Tunnicliffe, V. (1991) The biology of hydrothermal vents: ecology and evolution. Oceanography and Marine Biology Annual Review, 29, 319-407.

Van Dover, C.L., S.E. Humphris, D. Fornari, C.M. Cavanaugh, R. Collier, S.K. Goffredi, J. Hashimoto, M.D. Lilley, A.L. Reysenbach, T.M. Shank, K.L. VCon Damm, A. Banta, R.M. Gallant, D. Götz, D. Green, J. Hall, T.L. Harmer, L.A. Hurtado, P. Johnson, Z.P. McKiness, C. Meredith, E. Olson, I.L. Pan, M. Turnipseed, Y. Won, C.R. Young III, R.C. Vrijenhoek (2001) Biogeography and ecological setting of Indian Ocean hydrothermal vents. Science, 294, 818823.

Van Gaever, S., J. Galéron, M. Sibuet, A. Vanreusel (2009a) Deep-sea habitat heterogeneity influence on meiofaunal communities in the Gulf of Guinea. Deep Sea Research Part II: Topical Studies in Oceanography, 56(23), 2259-2269.

Van Gaever, S., L. Moodley, D. de Beer, A. Vanreusel (2006) Meiobenthos at the Arctic Håkon Mosby Mud Volcano, with a parental-caring nematode thriving in sulphide-rich sediments. Marine Ecology Progress Series, 321, 143-155.

Van Gaever, S., K. Olu, S. Derycke, A. Vanreusel (2009b) Metazoan meiofaunal communities at cold seeps along the norwegian margin: Influence of habitat heterogeneity and evidence for connection with shallow-water habitats. Deep Sea Research Part l: Oceanographic Research Papers, 56, 772-785.

Vanreusel, A., A.C. Andersen, A. Boetius, D. Connelly, M.R. Cunha, C. Decker, K. Heeschen, A. Hilario, K.A. Kormas, L. Maignien, K. Olu, M. Pachiadaki, B. Ritt, C. Rodrigues, J. Sarrazin, P.A. Tyler, S. Van Gaever, H. Vanneste (2009) Biodiversity of Cold Seep Ecosystems Along the European Margins. Oceanography, 22(1), 118-135. 
Vogt, P.R., G. Cherkashev, G. Ginsburg, G. Ivanov, A. Milkov, K. Crane, A. Lein, E. Sundvor, N. Pimenov, A. Egorov (1997) Haakon Mosby mud volcano provides unusual example of venting. Eos, 78(48), 549-557.

Zuhlke, K., D. Blome, H. Van Bernem, S. Dittmann (1998) Effects of the Tube-Building Polychaete Laniee eonehilega (PALLAS) on Benthic Macrofauna and Nematodes in an Intertidal Sandflat

Senckenbergiana maritima, 29(1), 131-138. 
Table 1: Habitats sampled at the Norwegian margin seep sites. Mesh size is the smallest sieve size used; all core samples were initially sieved on $500 \mu \mathrm{m}$. *non-quantitative samples.

\begin{tabular}{|c|c|c|c|c|c|c|c|c|}
\hline Sites and habitats & Cruise & $\begin{array}{l}\text { Latitude } \\
\left({ }^{\circ} \mathrm{N}\right)\end{array}$ & $\begin{array}{l}\text { Longitude } \\
\quad\left({ }^{\circ} \mathrm{E}\right)\end{array}$ & $\begin{array}{l}\text { Water } \\
\text { depth } \\
\text { (m) }\end{array}$ & $\begin{array}{l}\text { Dive } \\
\text { number }\end{array}$ & Sampling device & $\begin{array}{l}\text { Number of } \\
\text { replicates }\end{array}$ & Mesh size \\
\hline \multicolumn{9}{|l|}{ Håkon Mosby mud volcano } \\
\hline Centre & ARK-XXII & $72^{\circ} 00.31$ & $14^{\circ} 43.57$ & 1262 & $170-07$ & large blade corer & 3 & $\geq 250 \mu \mathrm{m}$ \\
\hline Grey microbial mats & ARK-XXII & $72^{\circ} 00.32$ & $14^{\circ} 43.50$ & 1262 & $167-04$ & large blade corer & 1 & $\geq 250 \mu \mathrm{m}$ \\
\hline White microbial mats & VICKING & $72^{\circ} 00.17$ & $14^{\circ} 43.94$ & 1258 & $276-06$ & blade corer & 3 & $\geq 500 \mu \mathrm{m}$ \\
\hline \multirow{3}{*}{$\begin{array}{l}\text { White microbial mats } \\
\text { Sediment adjacent to white } \\
\text { microbial mat } \\
\text { S. contortum field }\end{array}$} & VICKING & $72^{\circ} 00.19$ & $14^{\circ} 43.90$ & 1258 & $276-06$ & suction sampler & 3 & $\geq 250 \mu \mathrm{m}$ \\
\hline & VICKING & $72^{\circ} 00.19$ & $14^{\circ} 43.90$ & 1258 & $276-06$ & suction sampler & 3 & $\geq 250 \mu \mathrm{m}$ \\
\hline & VICKING & $72^{\circ} 00.34$ & $14^{\circ} 42.75$ & 1263 & $277-07$ & suction sampler & 6 & $\geq 250 \mu \mathrm{m}$ \\
\hline $\begin{array}{l}\text { Siboglinidae field: } 2 \text { species } \\
\text { dominated by S. contortum }\end{array}$ & VICKING & $72^{\circ} 00.33$ & $14^{\circ} 42.76$ & 1261 & $277-07$ & blade corer & 2 & $\geq 500 \mu \mathrm{m}$ \\
\hline O. haakonmosbiensis field & ARK-XXII & $72^{\circ} 00.34$ & $14^{\circ} 43.22$ & 1259 & $170-07$ & large blade corer & 3 & $\geq 250 \mu \mathrm{m}$ \\
\hline \multicolumn{9}{|l|}{$\begin{array}{l}\text { Storegga NE pockmark } \\
\text { (cne 5.6) }\end{array}$} \\
\hline S. cf. contortum field & VICKING & $64^{\circ} 45.27$ & $04^{\circ} 58.87$ & 746 & $275-05$ & suction sampler & 1 & $\geq 250 \mu \mathrm{m}$ \\
\hline S. cf. contortum field & VICKING & $64^{\circ} 45.27$ & $04^{\circ} 58.87$ & 745 & $275-05$ & blade corer & 2 & $\geq 500 \mu \mathrm{m}$ \\
\hline Gastropods* & VICKING & $64^{\circ} 45.27$ & $04^{\circ} 58.87$ & 745 & $275-05$ & suction sampler* & 2 & $\geq 250 \mu \mathrm{m}$ \\
\hline \multicolumn{9}{|l|}{$\begin{array}{l}\text { Nyegga pockmarks: } \\
\text { G11: }\end{array}$} \\
\hline S. cf. contortum field & VICKING & $64^{\circ} 39.98$ & $05^{\circ} 17.35$ & 732 & $272-02$ & suction sampler & 1 & $\geq 250 \mu \mathrm{m}$ \\
\hline S .cf. contortum field & VICKING & $64^{\circ} 39.99$ & $05^{\circ} 17.35$ & 732 & $272-02$ & blade corer & 2 & $\geq 500 \mu \mathrm{m}$ \\
\hline $\begin{array}{l}\text { Pingo with S. cf. contortum } \\
\text { G12: }\end{array}$ & VICKING & $64^{\circ} 40.00$ & $05^{\circ} 17.35$ & 736 & $272-02$ & large blade corer & 1 & $\geq 500 \mu \mathrm{m}$ \\
\hline $\begin{array}{l}\text { Gastropods and microbial } \\
\text { filaments* }\end{array}$ & VICKING & $64^{\circ} 39.79$ & $05^{\circ} 17.29$ & 732 & $272-02$ & suction sampler* & 1 & $\geq 250 \mu \mathrm{m}$ \\
\hline $\begin{array}{l}\text { Gastropods and microbial } \\
\text { filaments }\end{array}$ & VICKING & $64^{\circ} 39.79$ & $05^{\circ} 17.31$ & 732 & $272-02$ & suction sampler* & 1 & $\geq 250 \mu \mathrm{m}$ \\
\hline
\end{tabular}


Table 2: Sediment and water samples for chemical analysis on the habitats of Norwegian margin seep sites ( ${ }^{*}$ measurements performed with $\mathrm{H}_{2} \mathrm{~S}$ microsensors, otherwise sulphide was measured in porewater by photometry, PEP: water-pumping system).

\begin{tabular}{|c|c|c|c|c|c|c|c|c|}
\hline $\begin{array}{l}\text { Site and } \\
\text { habitats }\end{array}$ & Cruise & $\begin{array}{l}\text { Latitude } \\
\left({ }^{\circ} \mathrm{N}\right)\end{array}$ & $\begin{array}{c}\text { Longitude } \\
\left({ }^{\circ} \mathrm{E}\right)\end{array}$ & $\begin{array}{c}\text { Water } \\
\text { depth } \\
(\mathrm{m})\end{array}$ & $\begin{array}{c}\text { Dive } \\
\text { number }\end{array}$ & $\begin{array}{c}\text { Sampling } \\
\text { device }\end{array}$ & $\begin{array}{c}\begin{array}{c}\text { Number } \\
\text { of } \\
\text { replicates }\end{array} \\
\end{array}$ & $\begin{array}{l}\text { Measured } \\
\text { parameters }\end{array}$ \\
\hline \multicolumn{9}{|l|}{$\begin{array}{l}\text { Håkon } \\
\text { Mosby mud } \\
\text { volcano }\end{array}$} \\
\hline Centre $^{* a}$ & VICKING & $72^{\circ} 00.19$ & $14^{\circ} 43.88$ & 1258 & $276-06$ & $\begin{array}{l}\text { Tube } \\
\text { corer }\end{array}$ & 1 & $\begin{array}{l}\text { sulfide } \\
\text { profiles }\end{array}$ \\
\hline $\begin{array}{l}\text { Grey } \\
\text { microbial } \\
\text { mats }^{* b}\end{array}$ & VICKING & $72^{\circ} 00.31$ & $14^{\circ} 43.38$ & 1256 & $277-07$ & $\begin{array}{l}\text { Tube } \\
\text { corer }\end{array}$ & 2 & $\begin{array}{l}\text { sulfide } \\
\text { profiles }\end{array}$ \\
\hline $\begin{array}{l}\text { White } \\
\text { microbial } \\
\text { mats }^{* c}\end{array}$ & VICKING & $72^{\circ} 00.16$ & $14^{\circ} 43.95$ & 1258 & $276-06$ & $\begin{array}{l}\text { Tube } \\
\text { corer }\end{array}$ & 4 & $\begin{array}{l}\text { sulfide } \\
\text { profiles }\end{array}$ \\
\hline $\begin{array}{l}\text { White } \\
\text { microbial } \\
\text { mats }\end{array}$ & VICKING & $72^{\circ} 00.16$ & $14^{\circ} 43.92$ & 1258 & $276-06$ & PEP & 6 & $\mathrm{CH}_{4}$ \\
\hline $\begin{array}{l}\text { contortum } \\
\text { field }^{d}\end{array}$ & VICKING & $72^{\circ} 00.34$ & $14^{\circ} 42.74$ & 1264 & $277-07$ & $\begin{array}{l}\text { Tube } \\
\text { corer }\end{array}$ & 1 & $\begin{array}{c}\mathrm{O}_{2}, \mathrm{SO}_{4}{ }^{2-} \\
\text { and sulfide } \\
\text { profiles }\end{array}$ \\
\hline $\begin{array}{l}S . \\
\text { contortum } \\
\text { field }\end{array}$ & VICKING & $72^{\circ} 00.34$ & $14^{\circ} 42.75$ & 1264 & $277-07$ & PEP & 9 & $\mathrm{CH}_{4}$ \\
\hline \multicolumn{9}{|l|}{$\begin{array}{l}\text { Nyegga } \\
\text { pockmarks: } \\
\text { - G11: }\end{array}$} \\
\hline $\begin{array}{l}\text { Microbial } \\
\text { mats }\end{array}$ & VICKING & $64^{\circ} 39.98$ & $05^{\circ} 17.35$ & 732 & $272-02$ & PEP & 1 & $\mathrm{CH}_{4}$ \\
\hline Gastropods & VICKING & $64^{\circ} 39.99$ & $05^{\circ} 17.34$ & 732 & $272-02$ & $\begin{array}{l}\text { Tube } \\
\text { corer }\end{array}$ & 1 & $\begin{array}{c}\mathrm{O}_{2}, \mathrm{SO}_{4}{ }^{2-} \\
\text { and sulfide } \\
\text { profiles }\end{array}$ \\
\hline Gastropods & VICKING & $64^{\circ} 39.99$ & $05^{\circ} 17.34$ & 732 & 272-02 & PEP & 3 & $\mathrm{CH}_{4}$ \\
\hline $\begin{array}{l}\text { S. cf. } \\
\text { contortum } \\
\text { field }^{f}\end{array}$ & VICKING & $64^{\circ} 39.99$ & $05^{\circ} 17.34$ & 732 & $272-02$ & $\begin{array}{l}\text { Tube } \\
\text { corer }\end{array}$ & 1 & $\begin{array}{c}\mathrm{O}_{2}, \mathrm{SO}_{4}{ }^{2-} \\
\text { and sulfide } \\
\text { profiles }\end{array}$ \\
\hline $\begin{array}{l}\text { S. cf. } \\
\text { contortum } \\
\text { field }\end{array}$ & VICKING & $64^{\circ} 39.99$ & $05^{\circ} 17.35$ & 732 & $272-02$ & PEP & 1 & $\mathrm{CH}_{4}$ \\
\hline
\end{tabular}

Pangea events labels: a:VKG276/PC8, b: VKG277/PC7, VKG277/PC8, c: VKG276/PC2, VKG276/PC4, VKG276/PC10, VKG276/PC14, d: VKG277/PC24, e: VKG272/PC26, f : VKG276/PC25 
Table 3: Mean density (ind. $\mathrm{m}^{-2}$ ) and standard deviation (in parentheses) of macrofauna of the $\geq 500 \mu \mathrm{m}$ size fraction for the different habitats on HMMV and on Storegga slide pockmarks. Taxonomic richness (number of taxa) is given for each sampled habitat; when replicates were sampled, min and max are given. Total numbers of individual sampled are also given for the different habitats on HMMV and on Storegga slide pockmarks.

\begin{tabular}{|c|c|c|c|c|c|c|c|c|}
\hline \multirow[b]{2}{*}{ Taxa } & \multicolumn{5}{|c|}{ Håkon Mosby mud volcano } & \multicolumn{2}{|c|}{ Nyegga (G11) } & \multirow{2}{*}{$\begin{array}{c}\begin{array}{c}\text { Storegga } \\
\text { (cne 5.6) }\end{array} \\
\text { Siboglinidae } \\
\text { patch - S. cf. } \\
\text { contortum }\end{array}$} \\
\hline & Centre & $\begin{array}{c}\text { Grey microbial } \\
\text { mats }\end{array}$ & $\begin{array}{l}\text { White microbial } \\
\text { mats }\end{array}$ & $\begin{array}{c}\text { Siboglinidae patch - O. } \\
\text { haakonmosbiensis }\end{array}$ & $\begin{array}{c}\text { Siboglinidae patch } \\
\text { dominated by } S \text {. } \\
\text { contortum }\end{array}$ & $\begin{array}{c}\text { Siboglinidae } \\
\text { patch - S. cf. } \\
\text { contortum } \\
\end{array}$ & $\begin{array}{l}\text { Pingo - } S \text {. } \\
\text { cf. } \\
\text { contortum }\end{array}$ & \\
\hline \multicolumn{9}{|l|}{ Macrofaunal taxa : } \\
\hline Porifera & 0 & 0 & 0 & $1704(1916)$ & 0 & 0 & 56 & 0 \\
\hline Cnidaria & 0 & 0 & 0 & 0 & 0 & 0 & 56 & 0 \\
\hline Nemerta & 0 & 0 & 0 & $407(485)$ & $28(39)$ & 0 & 0 & 0 \\
\hline Sipuncula & 0 & 0 & 0 & 0 & $28(39)$ & $28(39)$ & 0 & $83(39)$ \\
\hline Polychaeta & $111(111)$ & 56 & $1315(1612)$ & $7648(1313)$ & $2278(864)$ & $1972(589)$ & 1139 & $8222(5500)$ \\
\hline Bivalvia & 0 & 0 & 0 & $74(128)$ & $500(314)$ & $944(79)$ & 583 & 2167 (1257) \\
\hline Gastropoda & $37(64)$ & 889 & 0 & $34611(31296)$ & $28(39)$ & 0 & 38250 & $28(39)$ \\
\hline Aplacophora & 0 & 0 & 0 & 0 & $28(39)$ & 0 & 0 & 0 \\
\hline Nudibranchia & 0 & 0 & 0 & 0 & $28(39)$ & 0 & 0 & 0 \\
\hline Amphipoda & 0 & 0 & 0 & 2222 (1392) & $1750(668)$ & 639 (39) & 722 & 778 (236) \\
\hline Isopoda & 0 & 0 & 0 & 315 (179) & $500(471)$ & $444(471)$ & 583 & $528(746)$ \\
\hline Tanaidacea & 0 & 56 & $37(64)$ & $19889(6890)$ & 222 & 1667 (1257) & 1306 & $83(39)$ \\
\hline Pantopoda & 0 & 0 & 0 & $833(494)$ & $861(39)$ & 0 & 0 & 0 \\
\hline Decapoda & 0 & 0 & 0 & $19(32)$ & 0 & 0 & 0 & 0 \\
\hline Ophiuroidea & 0 & 0 & 0 & $19(32)$ & 139 (196) & 0 & 0 & 0 \\
\hline Asteroidea & 0 & 0 & 0 & 0 & 0 & 0 & 0 & $28(39)$ \\
\hline $\begin{array}{l}\text { Holothuroidea } \\
\text { Total macrofaunal }\end{array}$ & 0 & 0 & 0 & 0 & 0 & 0 & 0 & $28(39)$ \\
\hline taxa (SD) & $148(170)$ & 1000 & $1352(1576)$ & 67741 (25 537) & $6389(2671)$ & 5695 (2239) & 42694 & $11944(7700)$ \\
\hline Taxonomic richness & 1 to 2 & 3 & 1 to 2 & 7 to 10 & 6 to 12 & 5 to 6 & 8 & 7 to 8 \\
\hline Total $(n b)$ & 6 & 18 & 73 & 3658 & 230 & 205 & 1537 & 430 \\
\hline \multicolumn{9}{|l|}{ Meiofaunal taxa : } \\
\hline Nematoda & 0 & 556 & $37(32)$ & $241(285)$ & $861(668)$ & $28(39)$ & 0 & $500(79)$ \\
\hline Copepoda & $93(64)$ & 222 & $37(32)$ & $1556(547)$ & $167(236)$ & $28(39)$ & 0 & $222(79)$ \\
\hline $\begin{array}{l}\text { Total meiofaunal } \\
\text { taxa (SD) } \\
\text { Mean total density }\end{array}$ & $93(64)$ & 778 & $74(32)$ & $1796(263)$ & $1028(904)$ & $56(79)$ & 0 & $722(157)$ \\
\hline (SD) & $241(170)$ & 1778 & $1426(1562)$ & 69537 (25601) & 7417 (3575) & $5750(2318)$ & 42694 & $12667(7542)$ \\
\hline Taxonomic richness & 1 to 3 & 5 & 2 to 3 & 9 to 11 & 7 to 14 & 6 to 7 & 8 & 8 to 10 \\
\hline Total $(\mathrm{nb})$ & 13 & 32 & 77 & 3755 & 267 & 207 & 1537 & 456 \\
\hline
\end{tabular}


Table 4: Mean density (ind. $\mathrm{m}^{-2}$ ) and standard deviation (SD) of polychaete from the $\geq 500 \mu \mathrm{m}$ size fraction for the different habitats on HMMV and on Storrega slide pockmarks. Diversity index (Taxonomic richness, Shannon-Wiener, Pielou's evenness and Simpson's index) are given for each sampled habitat; when replicates were sampled, standard deviation was given (in parenthese).

\begin{tabular}{|c|c|c|c|c|c|c|c|c|}
\hline \multirow[b]{2}{*}{ Polychaete families } & \multicolumn{5}{|c|}{ Håkon Mosby mud volcano } & \multicolumn{2}{|l|}{ Nyegga (G11) } & \multirow{2}{*}{$\begin{array}{c}\begin{array}{c}\text { Storegga } \\
\text { (cne 5.6) }\end{array} \\
\\
\text { Siboglinidae patch } \\
\text { S. cf. contortum }\end{array}$} \\
\hline & Centre & Grey microbial mats & White microbial mat & $\begin{array}{c}\text { Siboglinidae patch - } \\
\text { O. } \\
\text { haakonmosbiensis }\end{array}$ & $\begin{array}{l}\text { Siboglinidae patch } \\
\text { dominated by } S . \\
\text { contortum }\end{array}$ & $\begin{array}{l}\text { Siboglinidae patch - } \\
\text { S. cf. contortum }\end{array}$ & Pingo & \\
\hline Ampharetidae & 0 & 0 & 0 & 0 & 0 & 0 & 0 & $167(236)$ \\
\hline Amphinomidae & 0 & 0 & 0 & $333(314)$ & $806(275)$ & $250(275)$ & 139 & $1278(471)$ \\
\hline Capitellidae & $56(79)$ & 0 & $1259(1517)$ & $3000(1571)$ & 0 & 0 & 528 & $278(314)$ \\
\hline Chaetopteridae & 0 & 0 & 0 & 0 & 0 & $83(39)$ & 0 & 0 \\
\hline Cirratulidae & 0 & 0 & 0 & 0 & 56 & $111(79)$ & 0 & $56(79)$ \\
\hline Cossuridae & 0 & 0 & 0 & 0 & 0 & $28(39)$ & 0 & $222(79)$ \\
\hline Dorvilleidae & 0 & 0 & $37(64)$ & $4056(79)$ & 0 & 0 & 278 & $500(550)$ \\
\hline Flabelligeridae & 0 & 0 & 0 & 0 & 139 (118) & 0 & 0 & $194(196)$ \\
\hline Hesionidae & 0 & 0 & 0 & 0 & 0 & 0 & 0 & $28(39)$ \\
\hline Lumbrineridae & 0 & 0 & 0 & $28(39)$ & 111 & 361 (39) & 139 & 2556 (2593) \\
\hline Maldanidae & 0 & 0 & 0 & 0 & Presence & 0 & 0 & 0 \\
\hline Opheliidae & 0 & 0 & 0 & 0 & 0 & $28(39)$ & 28 & 0 \\
\hline Orbiniidae & 0 & 0 & 0 & 0 & 0 & 0 & 0 & $167(79)$ \\
\hline Paraonidae & 0 & 0 & 0 & 0 & 250 (196) & 833 & 0 & 472 (196) \\
\hline Pilargidae & 0 & 0 & 0 & 0 & $28(39)$ & 0 & 0 & 0 \\
\hline Polynoidae & 0 & 0 & 0 & 0 & $28(39)$ & $28(39)$ & 28 & 139 (118) \\
\hline Questidae & 0 & 0 & $19(32)$ & 0 & $639(746)$ & $194(118)$ & 0 & 1750 (904) \\
\hline Sabellidae & 0 & 0 & 0 & 0 & $28(39)$ & 0 & 0 & 0 \\
\hline Sphaerodoridae & 0 & 0 & 0 & 0 & 111 & 0 & 0 & 0 \\
\hline Spionidae & 0 & 0 & 0 & 0 & 0 & $56(79)$ & 0 & 222 (157) \\
\hline Syllidae & 0 & 0 & 0 & 0 & 0 & 0 & 0 & $139(118)$ \\
\hline Terrebellidae & 0 & 0 & 0 & 0 & 0 & 0 & 0 & $56(79)$ \\
\hline Trichobranchidae & 0 & 0 & 0 & 0 & $83(39)$ & 0 & 0 & 0 \\
\hline Indetermindated & 0 & 56 & 0 & 0 & 0 & 0 & 0 & 0 \\
\hline Mean Density (SD) & $56(79)$ & 56 & $1315(1612)$ & $7417(1768)$ & $2278(864)$ & $1972(589)$ & 1139 & $8222(5500)$ \\
\hline $\mathrm{Nb}$. Ind. & 2 & 1 & 71 & 267 & 82 & 71 & 41 & 296 \\
\hline S (Taxinomic richness) & 1 & 1 & 3 & 4 & 12 & 10 & 6 & 16 \\
\hline H (Shannon-Wiener) & 0 & 0 & 0.2 & 0.9 & 1.8 & 1.7 & 1.4 & 2.1 \\
\hline J (Pielou's evenness) & - & - & 0.2 & 0.6 & 0.8 & 0.8 & 0.8 & 0.8 \\
\hline Simpson's index & 0 & 0 & 0.1 & 0.5 & 0.8 & 0.8 & 0.7 & 0.8 \\
\hline
\end{tabular}


Table 5: Mean density (ind. $\mathrm{m}^{-2}$ ) and standard deviation (in parentheses) of macrofauna from the $\geq 250 \mu \mathrm{m}$ size fraction for the different habitats on HMMV and on Storegga slide pockmarks. Taxonomic richnesses (number of taxa) are given for each sampled habitat (line in italics); when replicates were sampled, min and max values are given. Total number of individual sampled are also given for the different habitats on HMMV and on Storegga slide pockmarks.

\begin{tabular}{|c|c|c|c|c|c|c|c|c|}
\hline \multirow[b]{2}{*}{ Taxa } & \multicolumn{6}{|c|}{ Håkon Mosby mud volcano } & \multirow{2}{*}{$\begin{array}{c}\begin{array}{c}\text { Nyegga } \\
\text { (G11) }\end{array} \\
\text { Siboglinida } \\
\text { e field } \\
\text { S. cf. } \\
\text { contortum }\end{array}$} & \multirow{2}{*}{$\begin{array}{c}\text { Storegga } \\
\text { (cne 5.6) } \\
\text { Siboglinida } \\
\text { e field } S . \\
\text { cf. } \\
\text { contortum }\end{array}$} \\
\hline & Centre & $\begin{array}{c}\text { Grey } \\
\text { microbial } \\
\text { mats }\end{array}$ & $\begin{array}{l}\text { White } \\
\text { microbial } \\
\text { mats }\end{array}$ & $\begin{array}{l}\text { Adjacent } \\
\text { sediment }\end{array}$ & $\begin{array}{c}\text { Siboglinidae field } \\
\text { O. } \\
\text { haakonmosbiensis }\end{array}$ & $\begin{array}{l}\text { Siboglinidae } \\
\text { field } \\
\text { S. contortum }\end{array}$ & & \\
\hline \multicolumn{9}{|l|}{$\begin{array}{l}\text { Macrofaunal } \\
\text { taxa: }\end{array}$} \\
\hline Porifera & 0 & 0 & 0 & 0 & $1704(1916)$ & 0 & 0 & 25 \\
\hline Cnidaria & 0 & 0 & 0 & 0 & 0 & 0 & 25 & 0 \\
\hline Nemerta & 0 & 0 & 0 & 0 & $296(306)$ & $117(120)$ & 50 & 25 \\
\hline Sipuncula & $\begin{array}{c}0 \\
167\end{array}$ & 0 & 0 & 0 & 0 & $354(262)$ & 75 & 50 \\
\hline Polychaeta & $(147)$ & 222 & $3525(412)$ & 2767 (2163) & 11259 (584) & $3725(1544)$ & 2300 & 3175 \\
\hline Bivalvia & 0 & 56 & $25(43)$ & 0 & 74 (128) & 4925 (2317) & 1175 & 650 \\
\hline Gastropoda & $37(64)$ & 1889 & 225 (139) & $417(363)$ & 47296 (31 408) & $171(147)$ & 950 & 250 \\
\hline Scaphopoda & 0 & 0 & 0 & 0 & 0 & $4(10)$ & 0 & 0 \\
\hline Aplacophora & 0 & 0 & 0 & 0 & 0 & $42(49)$ & 25 & 0 \\
\hline Amphipoda & 0 & 0 & 0 & 850 (1237) & 2926 (956) & 717 (270) & 1000 & 25 \\
\hline Cumacea & 0 & 0 & 0 & 0 & 0 & $17(30)$ & 25 & 0 \\
\hline Isopoda & $37(32)$ & 0 & 0 & 0 & 519 (449) & 2588 (1555) & 2175 & 225 \\
\hline Tanaidacea & 0 & 56 & 0 & $617(671)$ & 28000 (11 088) & $521(265)$ & 1000 & 0 \\
\hline Pantopoda & $19(32)$ & 0 & $8(14)$ & $333(513)$ & 833 (494) & 950 (562) & 0 & 0 \\
\hline $\begin{array}{l}\text { Caridae } \\
\text { Other }\end{array}$ & 0 & 0 & 0 & 0 & 0 & 0 & 175 & 0 \\
\hline Decapoda & 0 & 0 & 0 & 0 & $19(32)$ & 0 & 0 & 0 \\
\hline Cirripedia & 0 & 0 & 0 & 0 & 0 & $33(49)$ & 0 & 0 \\
\hline Ophiuroidea & 0 & 0 & 0 & $8(14)$ & $19(32)$ & 350 (172) & 275 & 50 \\
\hline Asteroidea & 0 & 0 & 0 & 0 & 0 & 0 & 25 & 0 \\
\hline $\begin{array}{l}\text { Mean density } \\
\text { of macrofaunal } \\
\text { taxa (SD) }\end{array}$ & $\begin{array}{l}259 \\
(179)\end{array}$ & 2222 & $3783(563)$ & $4992(2854)$ & 92955 (21 617) & $\begin{array}{l}14513 \\
(5453)\end{array}$ & 9275 & 4475 \\
\hline $\begin{array}{l}\text { raxonomic } \\
\text { Total (nb ind) }\end{array}$ & 1 to 3 & 4 & 2 to 4 & 5 to 6 & 8 to 10 & 10 to 14 & 14 & 9 \\
\hline & 14 & 39 & 454 & 599 & 5019 & 3483 & 371 & 179 \\
\hline
\end{tabular}




\begin{tabular}{|c|c|c|c|c|c|c|c|c|}
\hline $\begin{array}{l}\text { Meiofaunal } \\
\text { taxa : }\end{array}$ & & & & & & & & \\
\hline Nematoda & $\begin{array}{c}37(64) \\
5556\end{array}$ & 4889 & $\begin{array}{c}3642 \\
(1597)\end{array}$ & $\begin{array}{c}350(390) \\
7517\end{array}$ & $2685(1851)$ & $\begin{array}{l}10154 \\
(5734)\end{array}$ & 1750 & 3775 \\
\hline Copepoda & (8085) & 13167 & $433(260)$ & $(10159)$ & $12500(6233)$ & $1383(661)$ & 125 & 375 \\
\hline Ostracoda & 0 & 333 & 0 & 0 & 0 & $67(26)$ & 0 & 0 \\
\hline $\begin{array}{l}\text { Acari } \\
\text { Mean density }\end{array}$ & 0 & 56 & 0 & 0 & $19(32)$ & $13(21)$ & 0 & 0 \\
\hline $\begin{array}{l}\text { of meiofaunal } \\
\text { taxa (SD) }\end{array}$ & $\begin{array}{c}5593 \\
(8149)\end{array}$ & 18444 & $\begin{array}{c}4075 \\
(1857)\end{array}$ & $\begin{array}{c}7867(10 \\
544)\end{array}$ & $15204(8105)$ & $\begin{array}{l}11617 \\
(6259)\end{array}$ & 1875 & 4150 \\
\hline $\begin{array}{l}\text { Mean total } \\
\text { density (SD) } \\
\text { Taxonomic }\end{array}$ & $\begin{array}{c}5852 \\
(8265)\end{array}$ & 20667 & $\begin{array}{l}7858 \\
(2201)\end{array}$ & $\begin{array}{c}12858 \\
(12747)\end{array}$ & $108148(29059)$ & $\begin{array}{c}26129 \\
(11218)\end{array}$ & 11150 & $\begin{array}{c}8625 \\
11\end{array}$ \\
\hline richness & 2 to 5 & 8 & 4 to 6 & 7 to 8 & 10 to 12 & 11 to 17 & 16 & \\
\hline Total (nb ind) & 316 & 371 & 943 & 1543 & 5779 & 6274 & 476 & 345 \\
\hline
\end{tabular}

Table 6: Number of individuals and taxonomic richness (number of taxa) of $\geq 250 \mu \mathrm{m}$ macrofauna for the non-quantitatively sampled habitats on Storegga slide pockmarks.

\begin{tabular}{|lcccc|}
\hline & $\begin{array}{c}\text { Storegga pockmark } \\
\text { (cne 5.6) }\end{array}$ & $\begin{array}{c}\text { Nyegga pockmark } \\
\text { (G12) }\end{array}$ \\
\cline { 2 - 5 } Taxon & $\begin{array}{c}\text { Gastropods and } \\
\text { microbial filaments } \\
\text { Number of individuals/core }\end{array}$ & $\begin{array}{c}\text { Gastropods and } \\
\text { microbial filaments }\end{array}$ \\
\hline Polychaeta & 0 & 0 & 10 & 0 \\
Bivalvia & 0 & 1 & 0 & 0 \\
Gastropoda & 23 & 19 & 150 & 377 \\
Amphipoda & 1 & 0 & 2 & 7 \\
Copepoda & 1 & 0 & 0 & 0 \\
Tanaidacea & 0 & 0 & 0 & 1 \\
Decapoda & 0 & 0 & 0 & 1 \\
Total of individuals & 25 & 20 & 162 & 398 \\
Taxonomic richness & 3 & 2 & 3 & 5 \\
\hline
\end{tabular}


Table 7: Chemistry of pore water and of water above-sediment surface water at HMMV and in the G11 pockmark: oxygen penetration, sulphate fluxes and sulfide concentrations were measured in retrieved ROV tube cores (SD) and methane concentration from water sampled $5 \mathrm{~cm}$ above the seafloor. Results on HMMV from the literature are included to complete our data ( ${ }^{1}$ De Beer et al. 2006, ${ }^{2}$ Kaul et al. 2006, ${ }^{3}$ Niemann et al. 2006, ${ }^{4}$ Lichtschlag et al 2010). *, methane concentration measured $20 \mathrm{~cm}$ above the seafloor

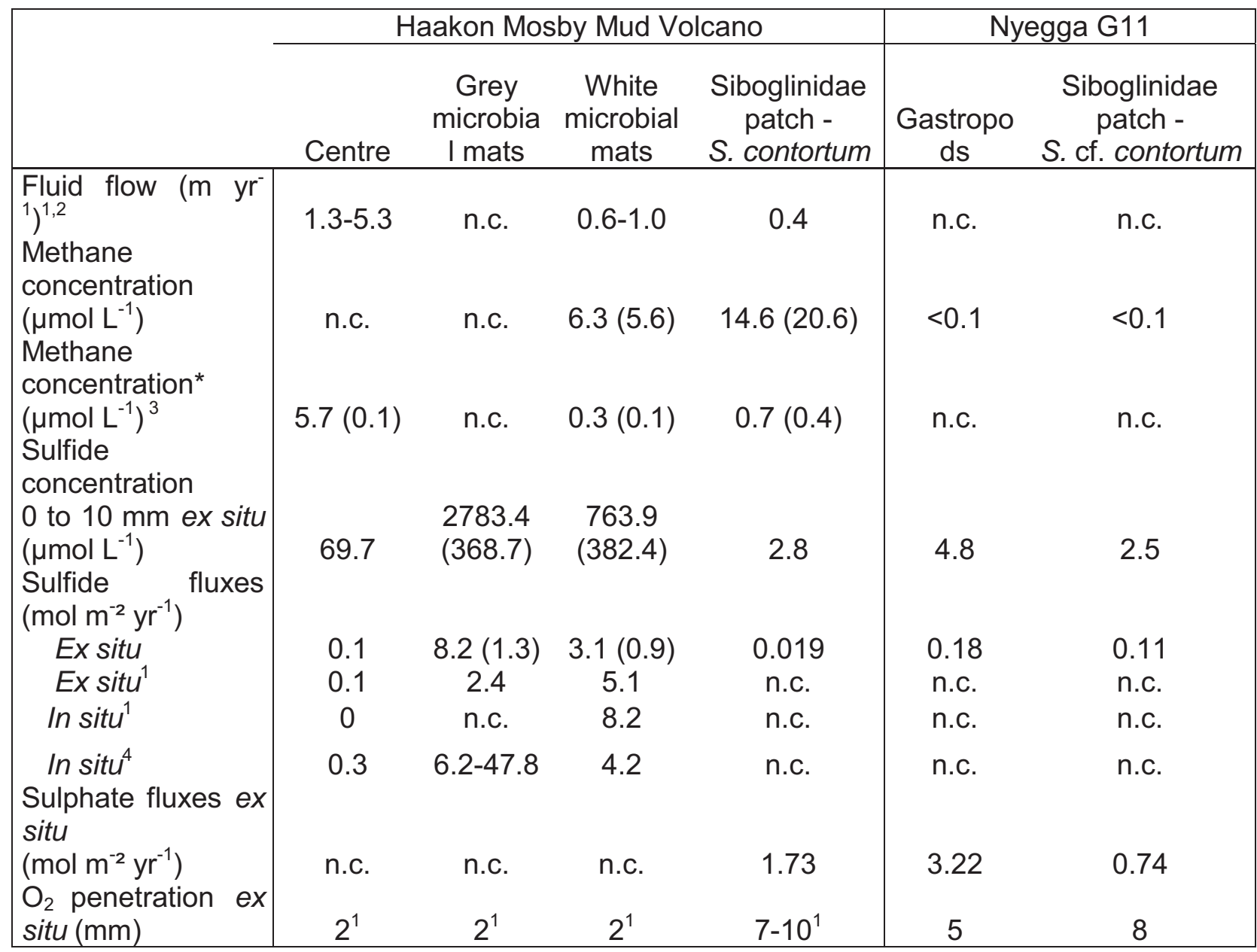


Table 8. Summary table of results obtained on macrofauna community structure for $\geq 500$ - and $\geq 250-\mu \mathrm{m}$ fractions.

\begin{tabular}{|c|c|c|c|c|c|c|c|c|c|}
\hline \multirow[b]{2}{*}{ habitat } & \multicolumn{6}{|c|}{ Håkon Mosby mud volcano } & \multicolumn{2}{|l|}{ Nyegga (G11) } & \multirow{2}{*}{$\begin{array}{l}\text { Storegga (cne 5.6) } \\
\text { Siboglinidae patch } \\
\text { - Sclerolinu cf. } \\
\text { contortum }\end{array}$} \\
\hline & centre & $\begin{array}{l}\text { grey } \\
\text { microbial } \\
\text { mats }\end{array}$ & $\begin{array}{l}\text { white } \\
\text { microbial } \\
\text { mats }\end{array}$ & $\begin{array}{l}\text { adjacent } \\
\text { sediment }\end{array}$ & $\begin{array}{l}\text { Siboglinidae patch } \\
\text { - Oligobrachia } \\
\text { haakonmosbiensis }\end{array}$ & $\begin{array}{l}\text { Siboglinidae patch } \\
\text { dominated by } \\
\text { Sclerolinum } \\
\text { contortum }\end{array}$ & $\begin{array}{l}\text { Siboglinidae patch } \\
\text { - Sclerolinum cf. } \\
\text { contortum }\end{array}$ & $\begin{array}{l}\text { Pingo - } \\
\text { Sclerolinu cf. } \\
\text { contortum }\end{array}$ & \\
\hline \multicolumn{10}{|l|}{ fauna $\geq 500 \mu \mathrm{m}$} \\
\hline $\begin{array}{l}\text { macrofaunal taxa } \\
\text { - dominant }\end{array}$ & Polychaeta & Gastropoda & Polychaeta & & $\begin{array}{l}\text { Gastropoda and } \\
\text { Tanaidacea }\end{array}$ & $\begin{array}{l}\text { Polychaeta and } \\
\text { Amphipoda }\end{array}$ & $\begin{array}{l}\text { Polychaeta and } \\
\text { Tanaidacea }\end{array}$ & $\begin{array}{l}\text { Gastropoda } \\
\text { and } \\
\text { Tanaidacea }\end{array}$ & $\begin{array}{l}\text { Polychaeta and } \\
\text { Bivalvia }\end{array}$ \\
\hline $\begin{array}{l}\text { macrofaunal } \\
\text { taxa density }\end{array}$ & $148(170)$ & 1000 & 1352 (1576) & & $67,741(25,537)$ & 6389 (2671) & $5695(2239)$ & 42,694 & $11,944(7700)$ \\
\hline taxonomic richness & $1-2$ & 3 & $1-2$ & & $7-10$ & $6-12$ & $5-6$ & 8 & $7-8$ \\
\hline $\begin{array}{l}\text { polychaete family } \\
\text { - dominant }\end{array}$ & Capitellidae & Undetermined & Capitellidae & & $\begin{array}{l}\text { Dorvilleidae and } \\
\text { Capitellidae }\end{array}$ & $\begin{array}{l}\text { Amphinomidae } \\
\text { and Questidae }\end{array}$ & $\begin{array}{l}\text { Lumbrineridae and } \\
\text { Amphinomidae }\end{array}$ & $\begin{array}{l}\text { Capitellidae } \\
\text { and } \\
\text { Dorvilleidae }\end{array}$ & $\begin{array}{l}\text { Lumbrineridae } \\
\text { and Questidae }\end{array}$ \\
\hline family richness & 1 & 1 & 3 & & 4 & 11 & 10 & 6 & 16 \\
\hline $\begin{array}{l}\text { meiofaunal taxa } \\
\text { - dominant }\end{array}$ & Copepoda & Nematoda & $\begin{array}{l}\text { Nematoda and } \\
\text { Copepoda }\end{array}$ & & Copepoda & Nematoda & $\begin{array}{l}\text { Nematoda and } \\
\text { Copepoda }\end{array}$ & & Nematoda \\
\hline $\begin{array}{l}\text { meiofaunal taxa } \\
\text { - density }\end{array}$ & $93(64)$ & 778 & $74(32)$ & & $1796(263)$ & $1028(904)$ & $56(79)$ & 0 & $722(157)$ \\
\hline total density & $241(170)$ & 1778 & $1426(1562)$ & & $69,537(25,601)$ & 7417 (3575) & $5750(2318)$ & 42,694 & $12,667(7542)$ \\
\hline $\begin{array}{l}\% \text { of macrofaunal } \\
\text { taxa }\end{array}$ & 62 & 56 & 95 & & 97 & 86 & 99 & 100 & 94 \\
\hline $\begin{array}{l}\% \text { of meiofaunal } \\
\text { taxa }\end{array}$ & 38 & 44 & 5 & & 3 & 14 & 1 & 0 & 6 \\
\hline $\begin{array}{l}\text { total taxonomic } \\
\text { richness }\end{array}$ & $1-3$ & 5 & $2-3$ & & $9-11$ & $7-14$ & $6-7$ & 8 & $8-10$ \\
\hline \multicolumn{10}{|l|}{ fauna $\geq 250 \mu \mathrm{m}$} \\
\hline $\begin{array}{l}\text { macrofaunal taxa } \\
\text { - dominant }\end{array}$ & Polychaeta & Gastropoda & Polychaeta & $\begin{array}{l}\text { Polychaeta and } \\
\text { Tanaidacea }\end{array}$ & $\begin{array}{l}\text { Gastropoda and } \\
\text { Tanaidacea }\end{array}$ & $\begin{array}{r}\text { Bivalvia and } \\
\text { Polychaeta }\end{array}$ & $\begin{array}{l}\text { Polychaeta } \\
\text { and Isopoda }\end{array}$ & & $\begin{array}{l}\text { Polychaeta an } \\
\text { Bivalvia }\end{array}$ \\
\hline $\begin{array}{l}\text { macrofaunal taxa } \\
\text { density }\end{array}$ & $259(179)$ & 2222 & $3783(563)$ & $4992(2854)$ & $92,955(21,617)$ & $14,513(5453)$ & 9275 & & 4475 \\
\hline taxonomic richness & $1-3$ & 4 & $2-4$ & $5-6$ & $8-10$ & $10-14$ & 14 & & 9 \\
\hline $\begin{array}{l}\text { meiofaunal taxa } \\
\text { - dominant }\end{array}$ & Copepoda & Copepoda & Nematoda & Copepoda & Copepoda & Nematoda & Nematoda & & Nematoda \\
\hline $\begin{array}{l}\text { meiofaunal taxa } \\
\text { - density }\end{array}$ & 5593 (8149) & 18,444 & $4075(1857)$ & $7867(10544)$ & $15,204(8105)$ & $11,617(6259)$ & 1875 & & 4150 \\
\hline total density & $5852(8265)$ & 20,667 & $7858(2201)$ & $12,858(12,747)$ & $108,148(29,059)$ & $26,129(11,218)$ & 11,150 & & 8625 \\
\hline $\begin{array}{l}\% \text { of macrofaunal } \\
\text { taxa density }\end{array}$ & 4 & 11 & 48 & 39 & 86 & 56 & 84 & & 52 \\
\hline $\begin{array}{l}\text { total taxonomic } \\
\text { richness }\end{array}$ & $2-5$ & 8 & $4-6$ & $7-8$ & $10-12$ & $11-17$ & 16 & & 11 \\
\hline
\end{tabular}




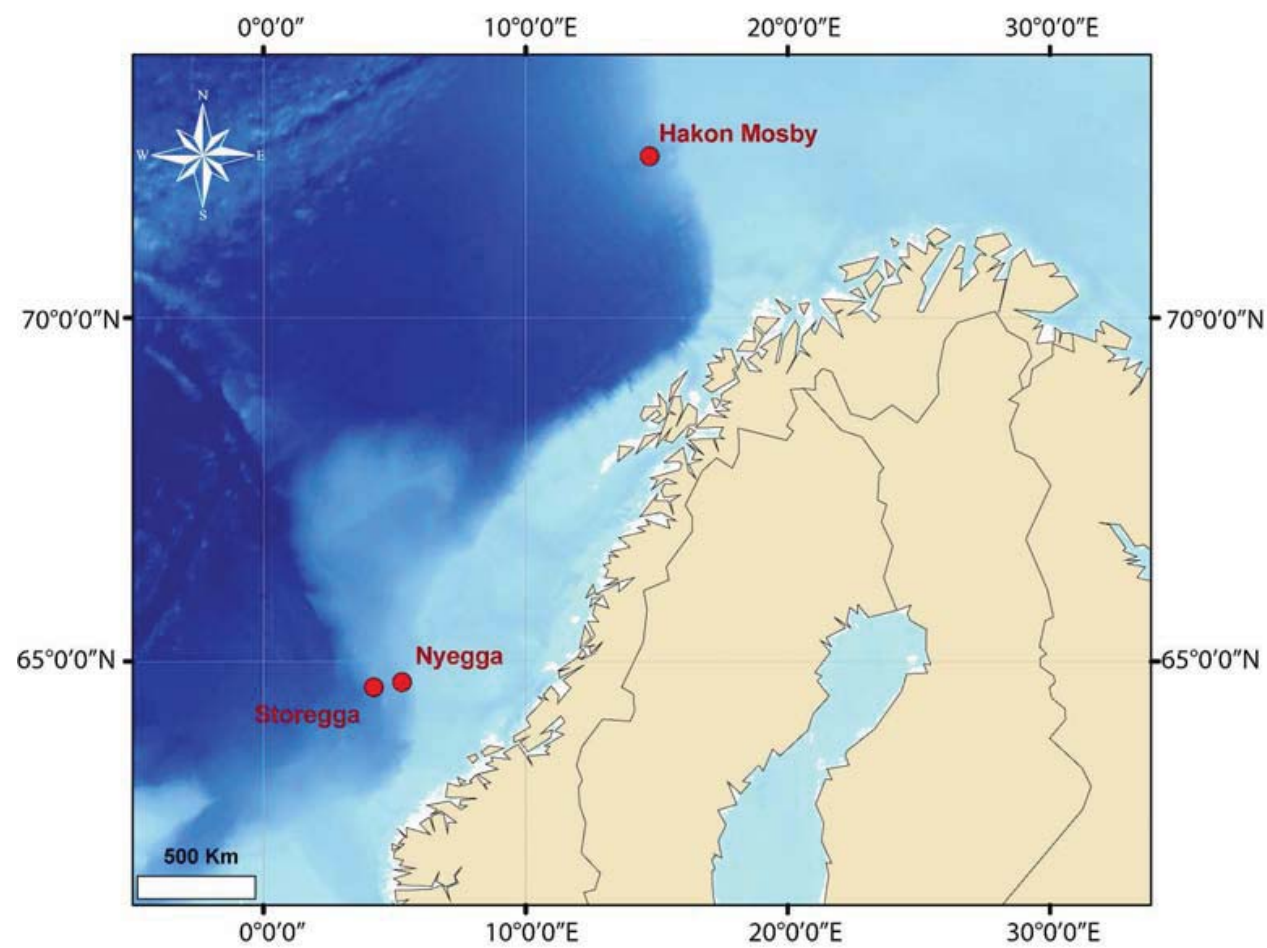

Figure 1: Location of the two seep areas that were sampled: Håkon Mosby mud volcano and Storegga slide, which encompasses the Nyegga area. $291 \times 225 \mathrm{~mm}(300 \times 300$ DPI $)$ 


\section{Page 55 of 65}

Marine Ecology

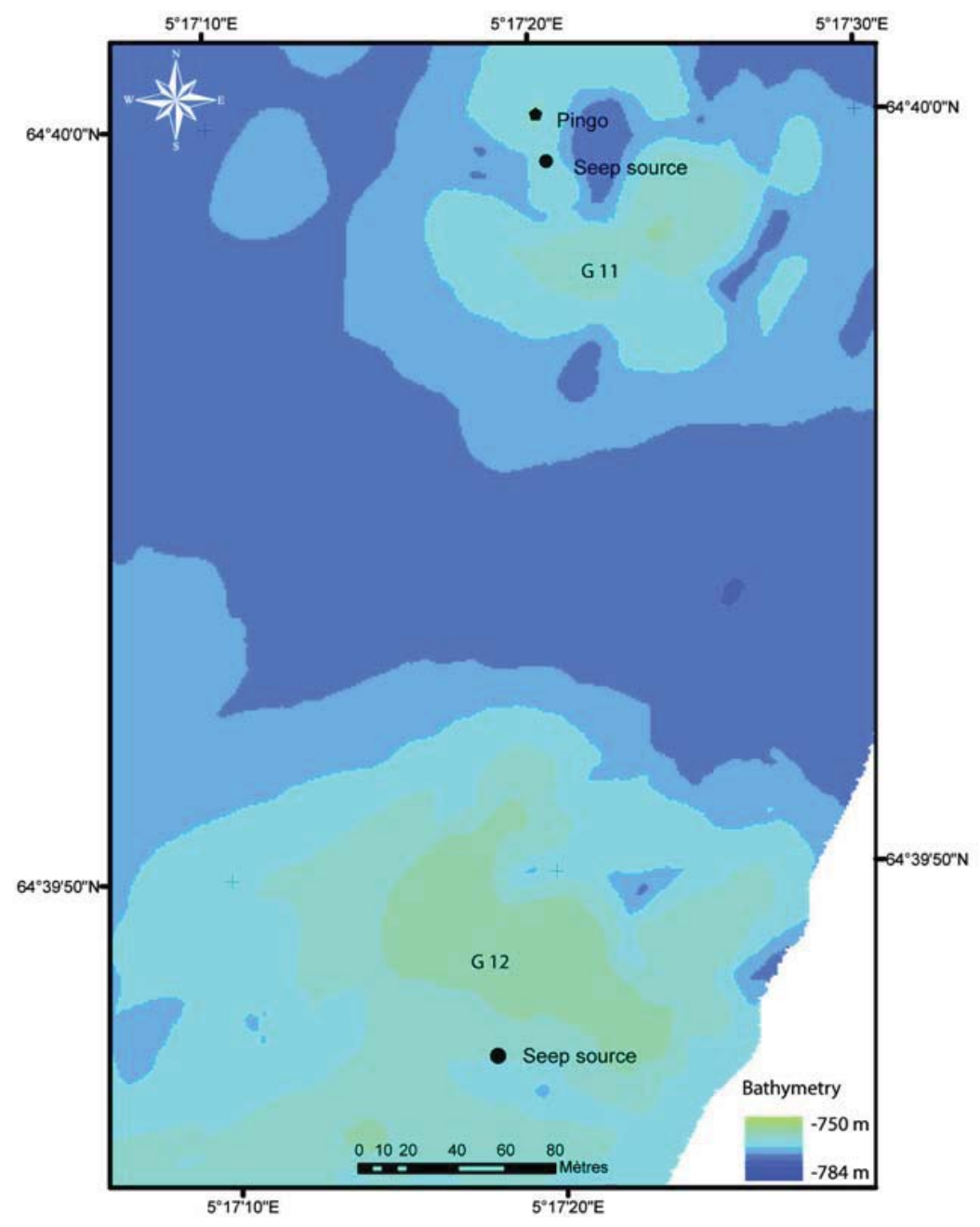

Figure 2: Location of the two pockmarks and the seep sources that were sampled on Nyegga: G11 and G12. Modified from M. Hovland. $208 \times 292 \mathrm{~mm}(300 \times 300$ DPI $)$ 


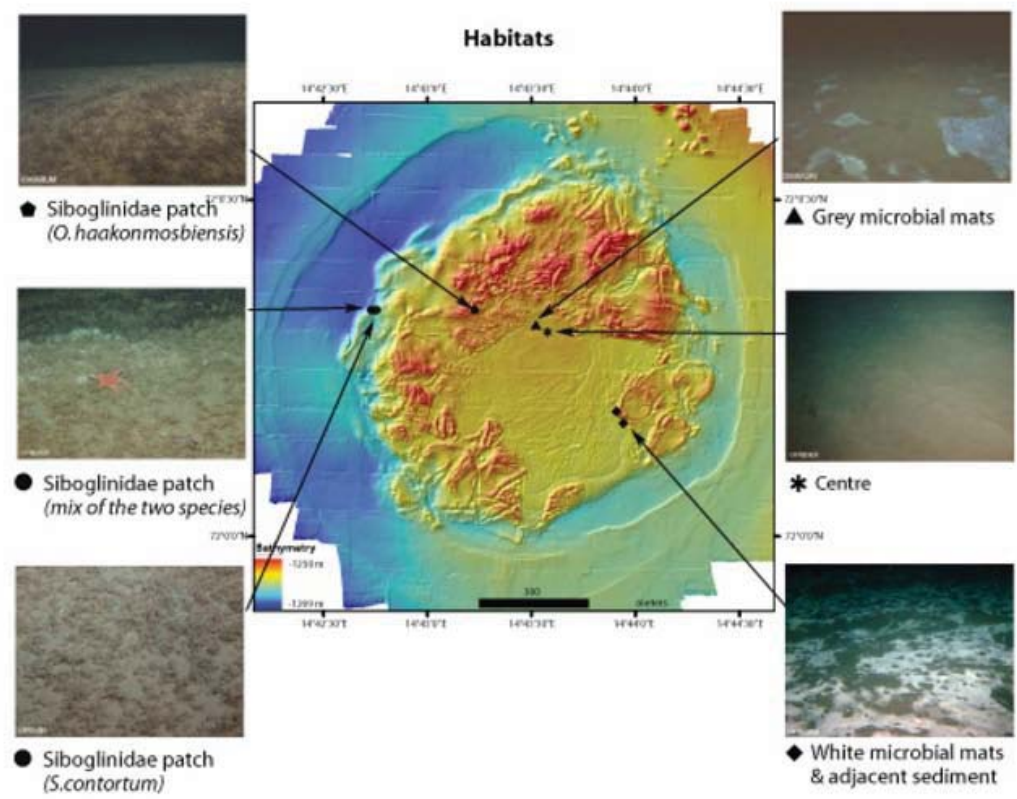

Figure 3: Location of the different habitats sampled on the Håkon Mosby mud volcano. Microbathymetry of HMMV was processed from a high-resolution multibeam echo-sounder mounted on the ROV Victor 6000 (Jerosch et al. 2007). $224 \times 186 \mathrm{~mm}(300 \times 300$ DPI) 


\section{Page 57 of 65}

1

4

5

7

8

9

10

11

12

13

14

15

16
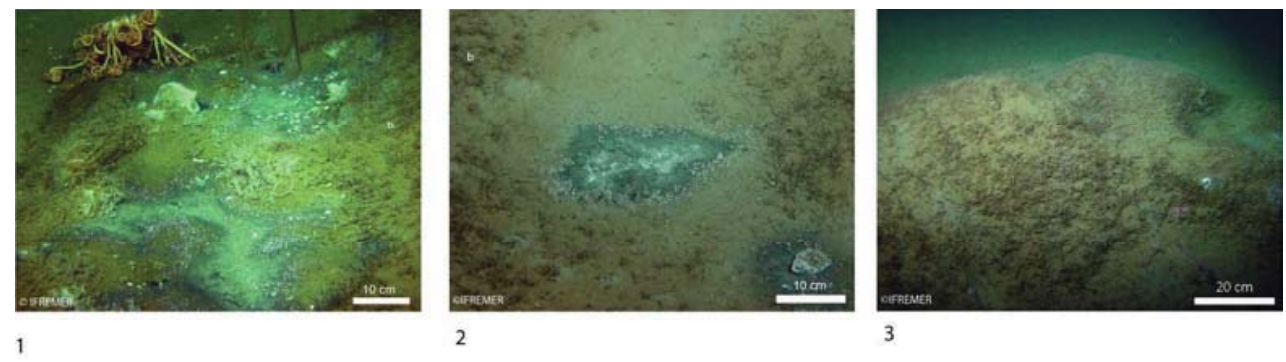

Figure 4: Habitats sampled on Storegga slide pockmarks. 1: Storegga, "cne 5.6" pockmark ; 2: Nyegga G11 pockmark (a: microbial filaments surrounded by gastropods; b: S. cf. contortum); 3: pingo on the G11 Nyegga pockmark colonised by S. cf. contortum $282 \times 78 \mathrm{~mm}(300 \times 300 \mathrm{DPI})$ 


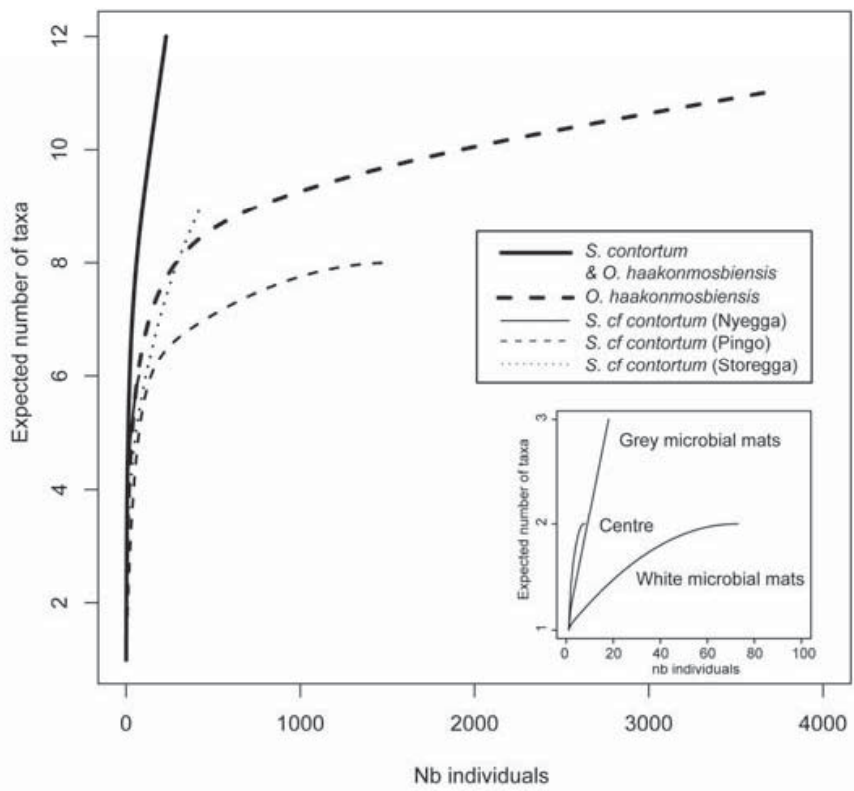

Figure 5: Rarefaction curves based on higher macrofaunal taxa on $500 \mu \mathrm{m}$ fraction at the different habitats of HMMV and Storegga slide. $246 \times 177 \mathrm{~mm}(300 \times 300$ DPI $)$ 


\section{Page 59 of 65}
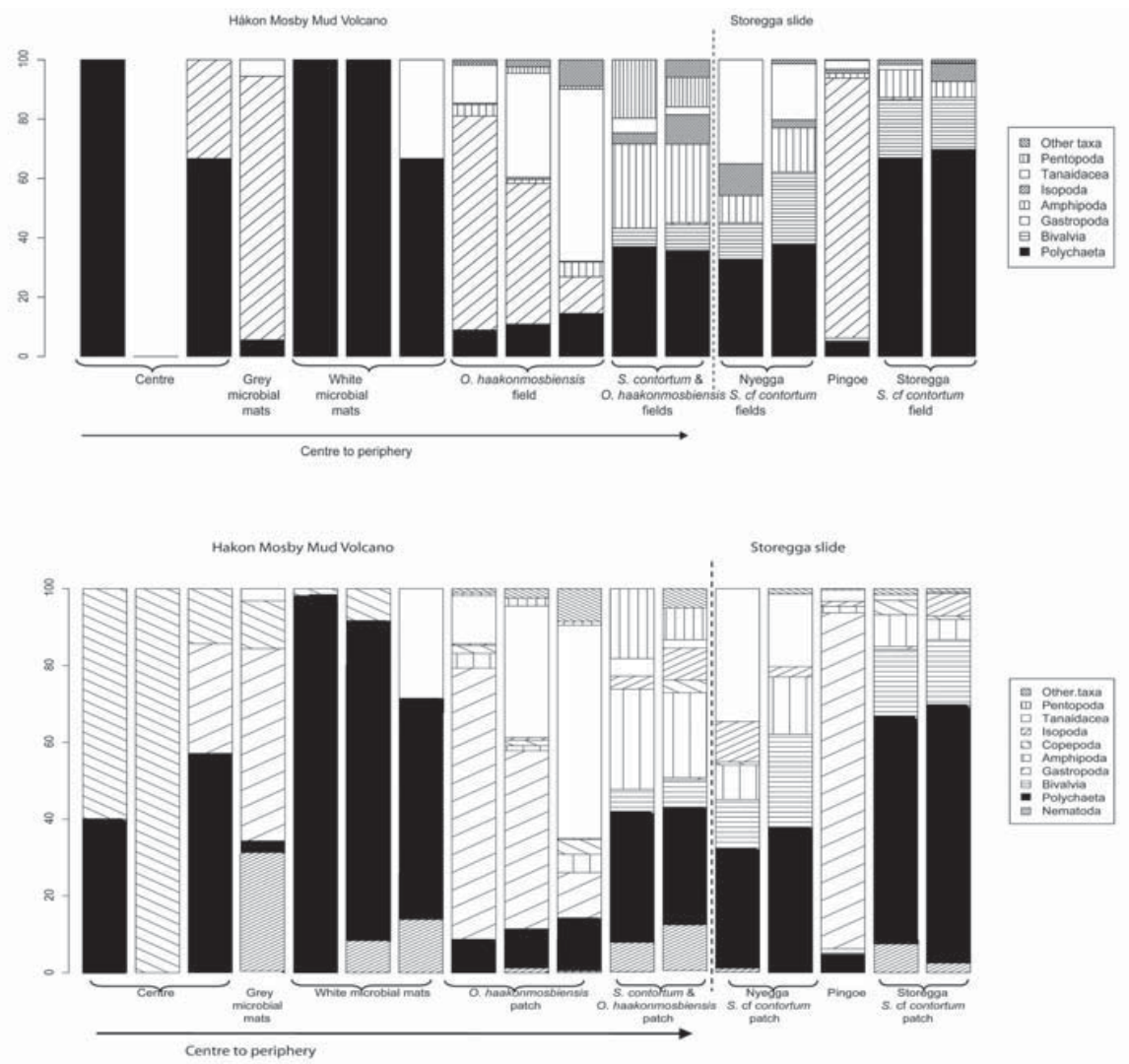

Figure 6: Relative density and taxonomic richness of macrofauna ( $\geq 500 \mu \mathrm{m}$ size fraction) (a) (with meiofaunal taxa (b)) on the different habitats on HMMV and on Storegga slide pockmarks. $217 \times 187 \mathrm{~mm}$ (300 x 300 DPI) 

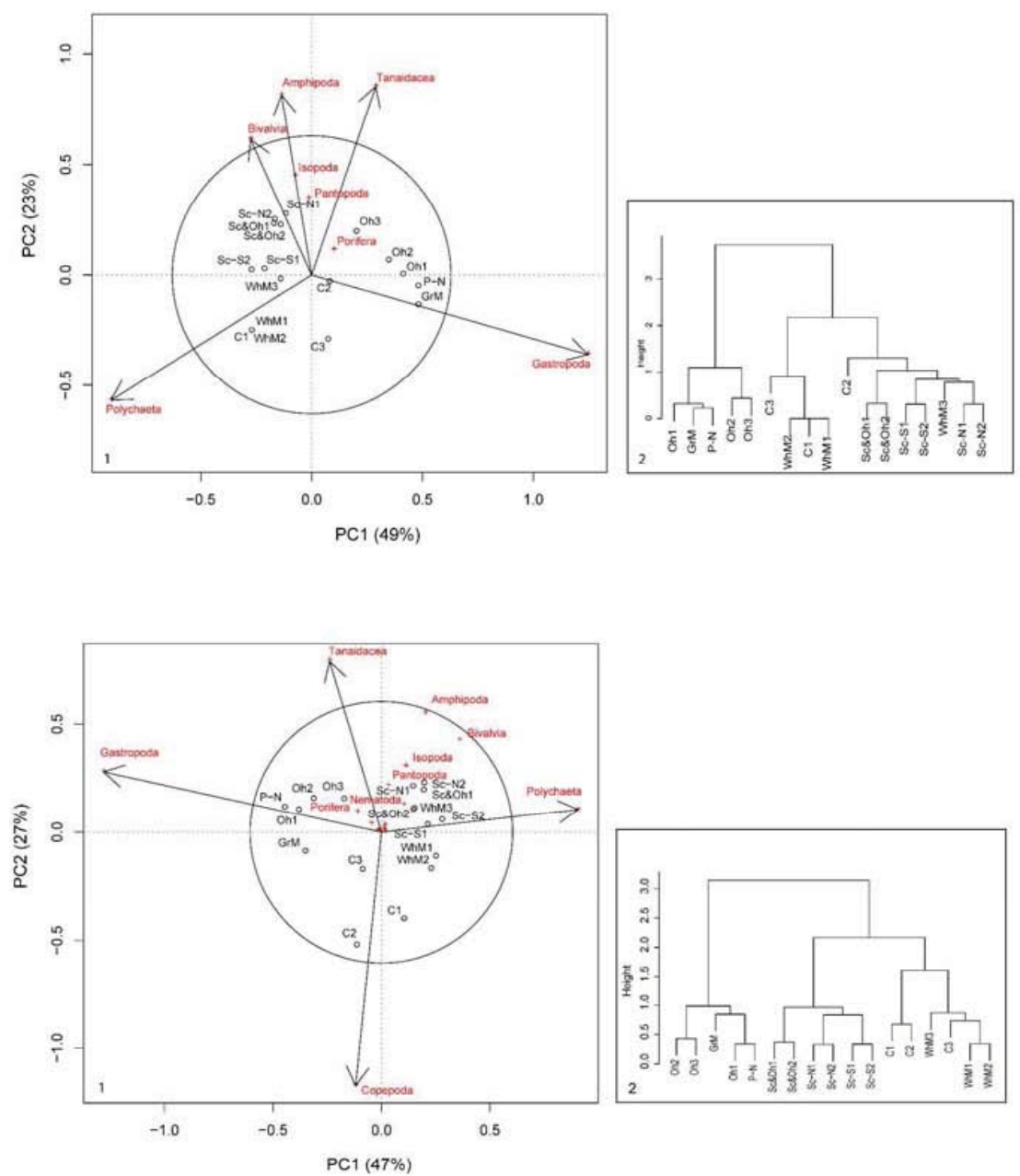

Figure 7: a) 1-PCA (scaling type 1) on $\geq 500 \mu \mathrm{m}$ macrofauna (macrofauna sensus stricto) with the circle of equilibrium contribution (radius $=0.61$ ) (only taxa with contributions of $>5 \%$ are represented) on HMMV and Storegga slide pockmarks. 2- Ward's hierarchical clustering performed with Hellinguer-transformed density. C: centre, Oh: O. haakonmosbiensis field, P-N: Pingo on G11 pockmark, Sc\&O: S. contortum and O. haakonmosbiensis field, Sc-N: S. cf. contortum field on the Nyegga (G11) pockmark, Sc-S: S. cf. contortum field on cne 5.6 pockmark, WhM: white microbial mats Sample without fauna is not represented (C2). b) 1-Same PCA scaling with meiofauna included (scaling type 1) (only taxa with contributions of $>5 \%$ are represented) on HMMV and Storegga slide pockmarks. 2- Ward's hierarchical clustering performed with Hellinguer-transformed density. C: centre, GrM: grey microbial mats, Oh: O. haakonmosbiensis field, P-N: Pingo on G11 pockmark, Sc\&O: S. contortum and O. haakonmosbiensis field, Sc-N: S. cf. contortum field on the Nyegga (G11) pockmark, Sc-S: S. cf. contortum field on cne 5.6 pockmark, WhM: white microbial mats. $289 \times 397 \mathrm{~mm}$ (300 x $300 \mathrm{DPI})$ 


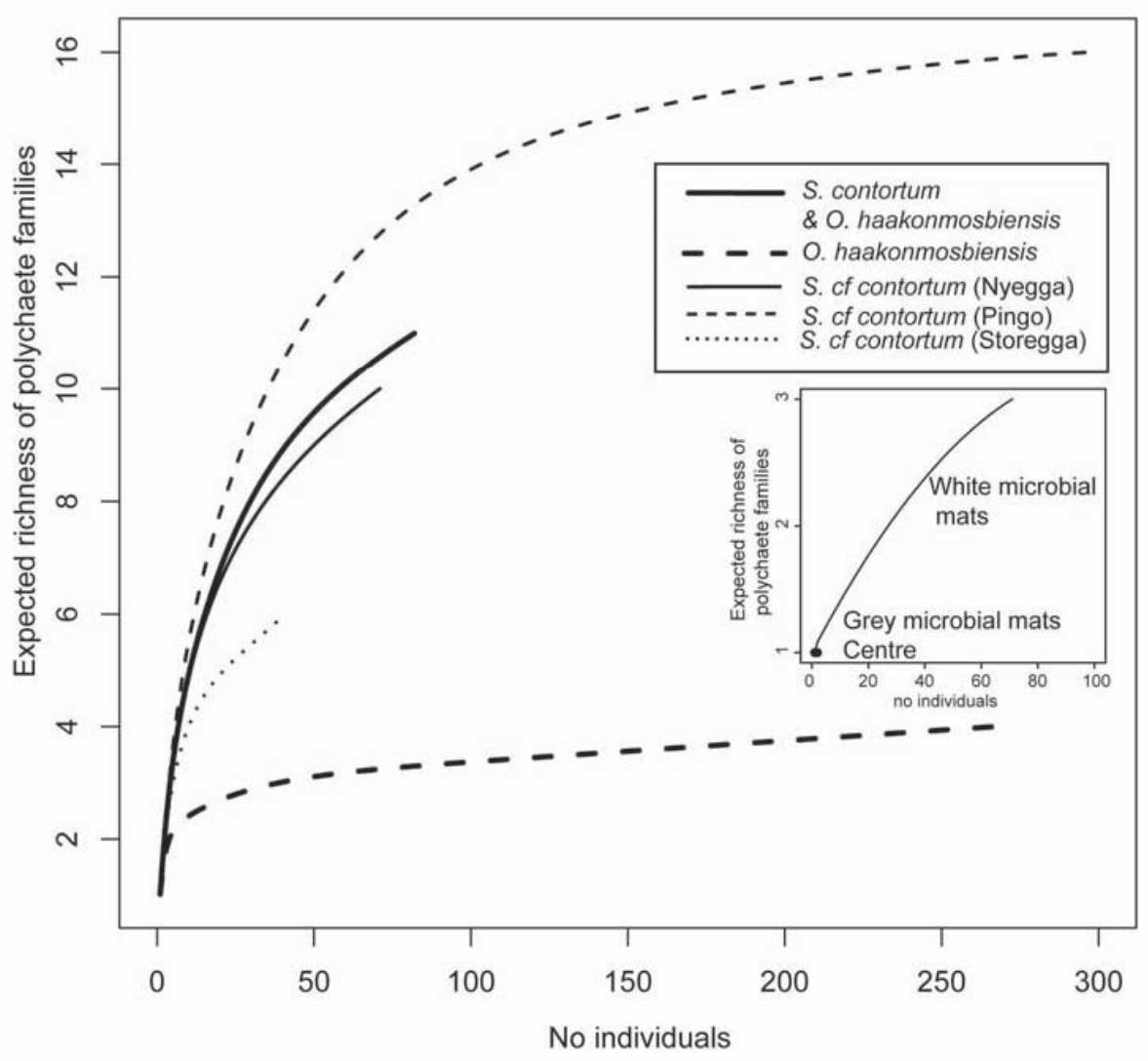

Figure 8: Rarefaction curves based on polychaete families ( $\geq 500 \mu \mathrm{m}$ size fraction) at the different habitats of HMMV and Storegga slide. $177 \times 177 \mathrm{~mm}(300 \times 300 \mathrm{DPI})$ 


\section{Page 63 of 65}

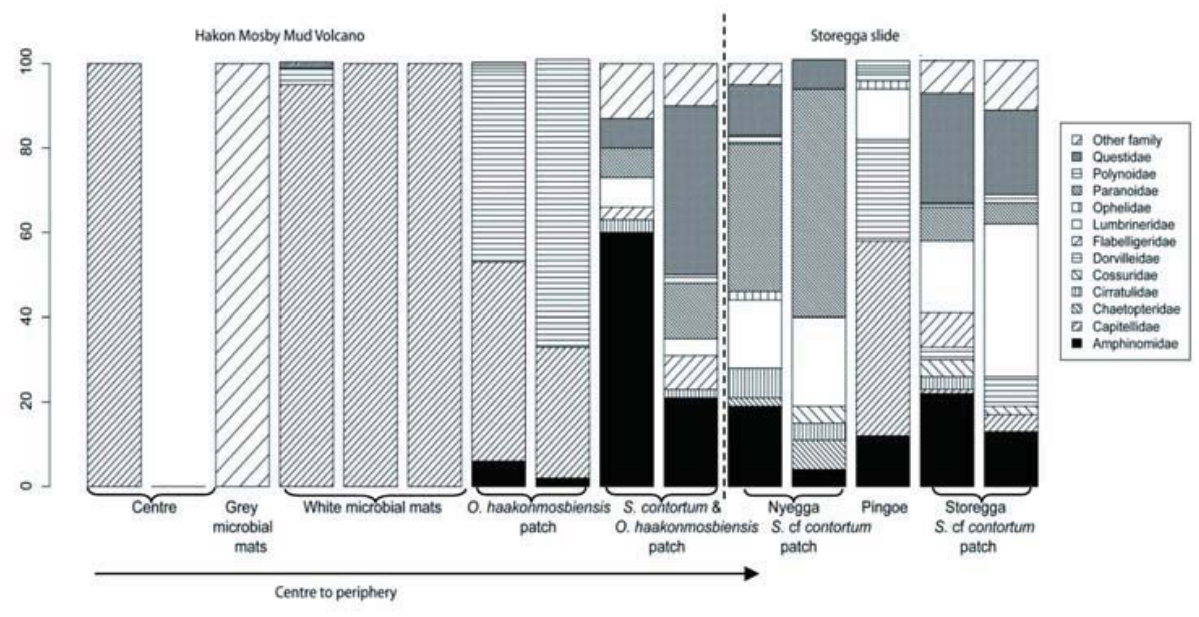

Figure 9: Relative density and family richness of polychaetes ( $\geq 500 \mu \mathrm{m}$ size fraction) on the different habitats on HMMV and on Storegga slide pockmarks. $241 \times 126 \mathrm{~mm}(300 \times 300 \mathrm{DPI})$ 

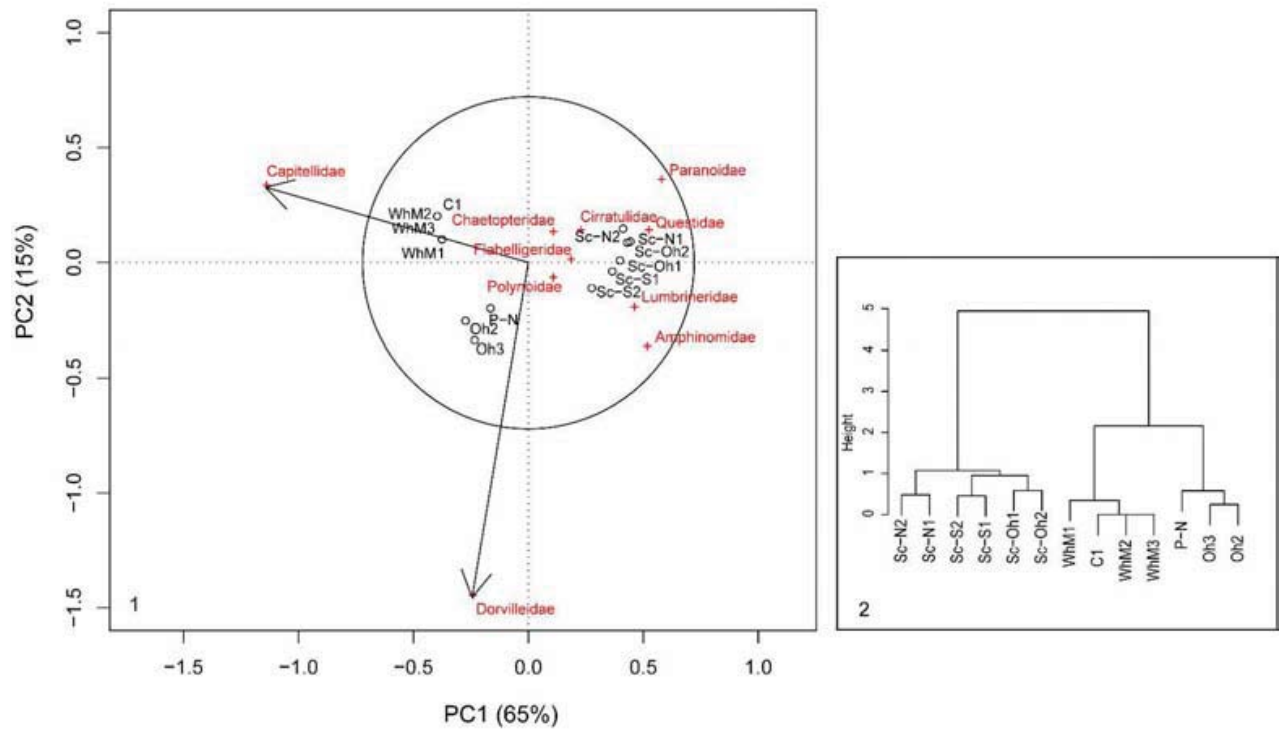

Figure 10: 1-PCA (scaling type 1 ) on $\geq 500 \mu \mathrm{m}$ polychaete families with the circle of equilibrium contribution (radius $=0.70$ ), only families with contributions of $>10 \%$ are represented on HMMV and Storegga slide pockmarks. 2- Ward's hierarchical clustering performed with Hellinguer-transformed density. C: centre, Oh: O. haakonmosbiensis field, P-N: Pingo on G11 pockmark, Sc\&O: S. contortum and $\mathrm{O}$. haakonmosbiensis field, Sc-N: S. cf. contortum field on the Nyegga (G11) pockmark, Sc-S: S. cf. contortum field on cne 5.6 pockmark, WhM: white microbial mats. Samples without polychaete $(\mathrm{C} 2)$ or with unidentified polychaete $(\mathrm{GrM})$ are not represented $267 \times 177 \mathrm{~mm}(300 \times 300 \mathrm{DPI})$ 


\section{Page 65 of 65}
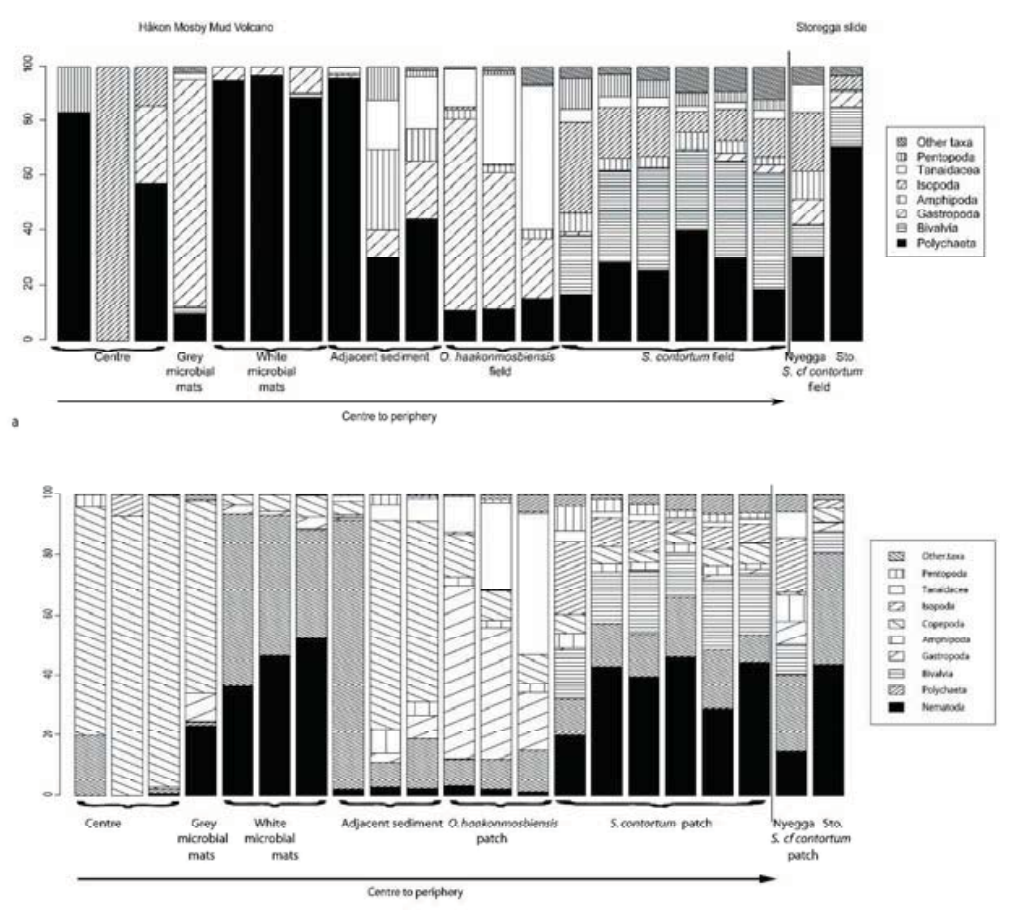

Figure 11: Relative density and taxonomic richness of macrofauna $\geq 250 \mu \mathrm{m}$ (a) (with meiofaunal taxa (b)) sampled on the different habitats of HMMV and on Storegga slide pockmarks $447 \times 382 \mathrm{~mm}(300 \times 300 \mathrm{DPI})$ 


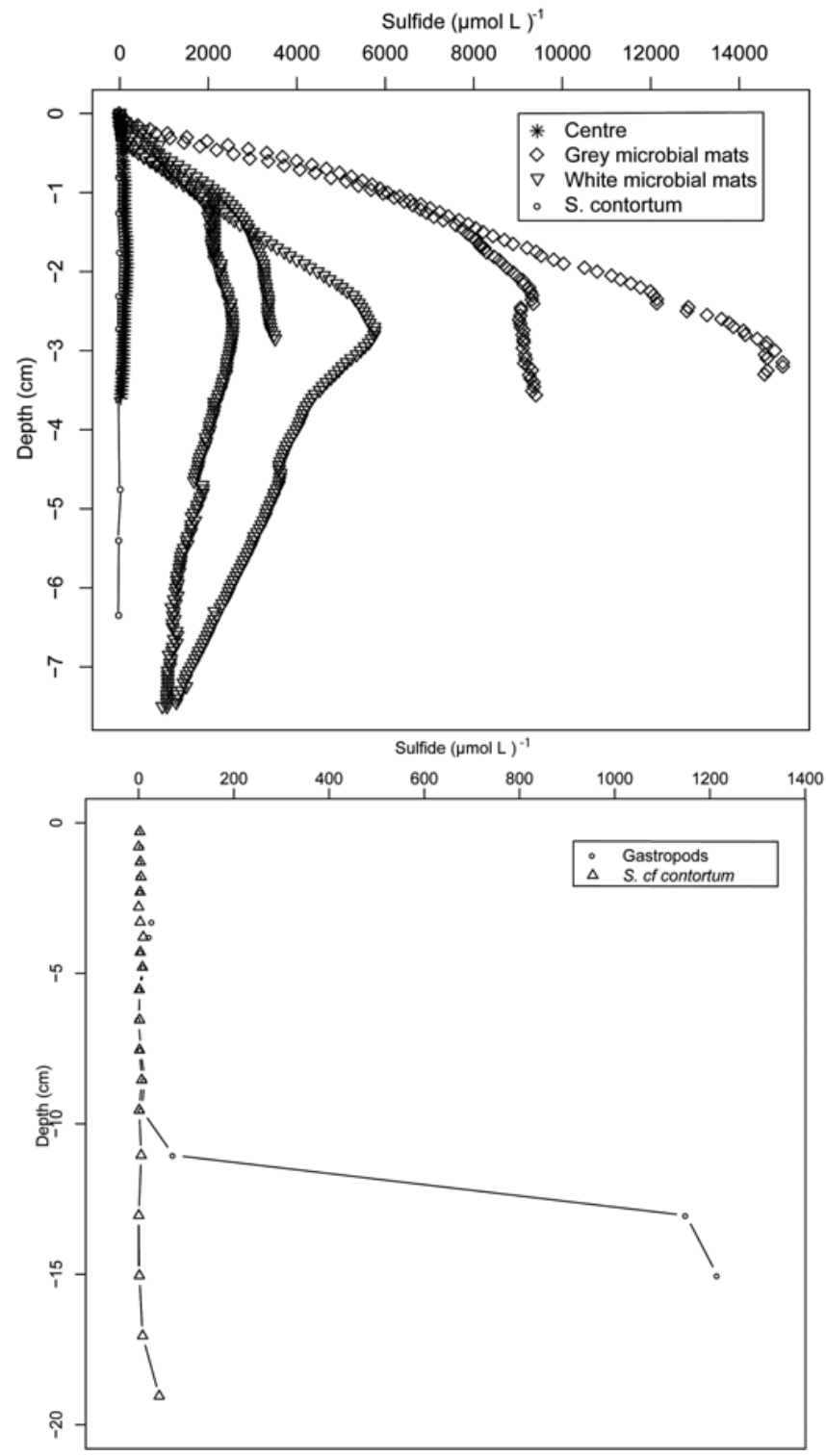

Figure 12: Sulfide profiles on HMMV (a) and in G11 pockmark (b). $177 \times 298 \mathrm{~mm}(300 \times 300$ DPI) 